\title{
Differential Diagnosis of the Short IGF-I-Deficient Child with Apparently Normal Growth Hormone Secretion
}

\author{
Jan M. Wit ${ }^{\mathrm{a}}$ Sjoerd D. Joustra ${ }^{\mathrm{a}}$ Monique Losekoot ${ }^{\mathrm{b}}$ \\ Hermine A. van Duyvenvoorde ${ }^{b}$ Christiaan de Bruin ${ }^{a}$ \\ aDepartment of Paediatrics, Leiden University Medical Centre, Leiden, The Netherlands; \\ bDepartment of Clinical Genetics, Leiden University Medical Centre, Leiden, The Netherlands
}

\section{Keywords}

Growth hormone - Insulin-like growth factor I - Short stature - Growth hormone receptor - STAT5B - GH1 - GHSR . IGFALS · IGFIR

\begin{abstract}
The current differential diagnosis for a short child with low insulin-like growth factor I (IGF-I) and a normal growth hormone $(\mathrm{GH})$ peak in a $\mathrm{GH}$ stimulation test (GHST), after exclusion of acquired causes, includes the following disorders: (1) a decreased spontaneous $\mathrm{GH}$ secretion in contrast to a normal stimulated GH peak ("GH neurosecretory dysfunction," GHND) and (2) genetic conditions with a normal GH sensitivity (e.g., pathogenic variants of GH1 or GHSR) and (3) GH insensitivity (GHI). We present a critical appraisal of the concept of GHND and the role of 12- or 24-h GH profiles in the selection of children for GH treatment. The mean 24-h GH concentration in healthy children overlaps with that in those with $\mathrm{GH}$ deficiency, indicating that the previously proposed cutoff limit (3.0-3.2 $\mu \mathrm{g} / \mathrm{L})$ is too high. The main advantage of performing a GH profile is that it prevents about $20 \%$ of falsepositive test results of the GHST, while it also detects a low spontaneous $\mathrm{GH}$ secretion in children who would be consid-
\end{abstract}

karger@karger.com www.karger.com/hrp

Karger"

GOPEN ACCESS
(C) 2021 The Author(s)

Published by S. Karger AG, Basel

This is an Open Access article licensed under the Creative Commons Attribution-NonCommercial-4.0 International License (CC BY-NC) (http://www.karger.com/Services/OpenAccessLicense), applicable to the online version of the article only. Usage and distribution for commercial purposes requires written permission. ered GH sufficient based on a stimulation test. However, due to a considerable burden for patients and the health budget, $\mathrm{GH}$ profiles are only used in few centres. Regarding genetic causes, there is good evidence of the existence of Kowarski syndrome (due to $G H 1$ variants) but less on the role of GHSR variants. Several genetic causes of (partial) $\mathrm{GHI}$ are known (GHR, STAT5B, STAT3, IGF1, IGFALS defects, and Noonan and $3 \mathrm{M}$ syndromes), some responding positively to $\mathrm{GH}$ therapy. In the final section, we speculate on hypothetical causes.

(c) 2021 The Author(s)

Published by S. Karger AG, Basel

\section{Introduction}

In the diagnostic approach of the short and/or slowly growing child, serum insulin-like growth factor I (IGF-I) is considered one of the essential components of the laboratory screening procedure, as a first indication for growth hormone (GH) deficiency (GHD) or insensitivity (GHI) [1-5]. If serum IGF-I is low (or in the lower half of the reference range) for age, sex, and pubertal stage, the next step is usually to assess the endogenous GH reserve by a GH stimulation test (GHST). The results of 2 GHSTs,
Correspondence to:

Jan M. Wit, j.m.wit@lumc.nl 
performed separately or combined on the same day [6], serve as a proxy indicator of GH secretion. If the diagnosis of GHD is established, magnetic resonance imaging of the hypothalamic/pituitary region is indicated to search for the anatomical cause [7].

Unfortunately, there are important drawbacks with the use of both diagnostic tools (serum IGF-I and GHST). The assessment of the circulating IGF-I concentration is hampered by different assays and standards, and there is scarcity of reference data, particularly for pubertal stage $[2,4,8,9]$. Also, GHSTs suffer from serious disadvantages, as already highlighted more than 25 years ago [10], and we wish to highlight 6 examples.

First, different pharmacological agents generate different mean GH peak sizes, with poor correlations among tests [11-16]. For example, the peak GH in response to pharmacological stimulation with clonidine is significantly higher than the response to arginine, insulin [17], and glucagon [16]. Second, there is no published guidance on differentiating the cutoff of the GH peak in a GHST between prepubertal and pubertal children, while GH peaks are considerably higher in puberty due to increased sex hormone (mainly oestrogen) concentrations $[18,19]$. Third, there is no consensus on the use and timing of sex steroid priming in prepubertal young teenagers [7], despite the recommendation in the recent US guideline [6]. Fourth, a high BMI (probably mainly due to high fat mass, leading to increased rate of degradation, reviewed in [20]) has a negative effect on the GH peak [21], but it is unknown how to adjust for this effect. Fifth, the cutoff for the GH peak is arbitrary, and the change in conversion factor from the $\mathrm{GH}$ bioassay (mU/L) to mass units $(\mu \mathrm{g} / \mathrm{L})$ by increasing purity of the $\mathrm{GH}$ preparations has further complicated the situation. This is illustrated by the change of the cutoff for a "normal" GH peak over time, from $15 \mathrm{mU} / \mathrm{L}$ (then equivalent to $7.5 \mu \mathrm{g} / \mathrm{L}$ ) via 20 $\mathrm{mU} / \mathrm{L}(10 \mu \mathrm{g} / \mathrm{L}$ ) to $30 \mathrm{mU} / \mathrm{L}$ (equivalent to $10 \mu \mathrm{g} / \mathrm{L}$ when a more pure laboratory standard [ $1 \mathrm{mg}=3 \mathrm{IU}$ ] had been introduced) and back to approximately $20 \mathrm{mU} / \mathrm{L}$ (6.7-7 $\mu \mathrm{g} / \mathrm{L})[7,22]$. Finally, the reproducibility of a GHST is low [14], probably caused partially by the effect of a variable interval between the pharmacological agent and the foregoing spontaneous GH pulse (the refractory interval is estimated at $3 \mathrm{~h}[23,24])$. All these uncertainties have led to a large variation in clinical practice around the world with regard to GHSTs $[25,26]$.

If in a short child with a low serum IGF-I, a "classical" GHD is excluded by a normal stimulated GH peak, one should first try to assess whether the sensitivity to GH is normal or decreased. In the excellent review by Storr et al. [27], GHI was defined as "impairment of all or some of the mechanisms of physiological GH action." According to this definition, all disorders of the GH-IGF axis except GHD belong to this diagnostic category, irrespective of the serum IGF-I concentration, also including some syndromes with dysmorphic features (e.g., Noonan and three $\mathrm{M}[3 \mathrm{M}]$ syndromes), IGF2 defects, and GH neutralizing antibodies in patients with a $G H 1$ gene deletion. We prefer to rather call this "decreased responsiveness" to GH and prefer to restrict the term GHI to disorders with a low serum IGF-I concentration in spite of a normal GH secretion, so only including disorders of the $\mathrm{GH}$ receptor and post-receptor signalling and its main target hormones (IGF-I and acid-labile subunit [ALS]). We thus exclude disorders of the GH-IGF axis with a normal or increased serum IGF-I caused by genetic defects of IGF1R, IGF2, or PAPPA2 and genetic disorders affecting post-receptor signalling of the IGF-I receptor [28], which still fall under the umbrella of GH unresponsiveness.

The logical diagnostic step to assess GH sensitivity is to measure the change in circulating IGF-I after a certain period of GH administration. Initially, this was used to identify children who would be expected to respond positively to GH injections [29-31]. Later, when recombinant human IGF-I (rhIGF) became available, the test was named "IGF-I generation test" (IGFGT) and mainly used to estimate the likelihood of Laron syndrome [32]. That regimen consisted of a series of 4 daily GH injections of a single dosage $(33 \mu \mathrm{g} / \mathrm{kg} \cdot$ day $)$. Later, more complex regimens of the IGFGT were investigated, consisting of several periods of escalating $\mathrm{GH}$ dosages $[33,34]$. At present, multiple regimens are being used and the sensitivity and specificity to detect molecularly proven cases of GHI are reportedly high, although "the ability of the IGFGT to detect less severe GHI is doubtful” [35].

Over the past 15 years, the IGFGT has been used in the Netherlands in a standardized format for children with severe short stature (height less than -2.5 standard deviation score [SDS]), persistent low IGF-1 (less than -2 SDS) and a normal stimulated $\mathrm{GH}$ peak $(>10 \mu \mathrm{g} / \mathrm{L})$, using a schedule of 1,2 or 3 escalating GH doses $(0.7,1.4$ and 2.8 $\mathrm{mg} / \mathrm{m}^{2}$. day) for 1 week each, with minimal intervals of 4 weeks. If the child's serum IGF-I SDS response is $<1 \mathrm{SD}$, the response is assessed on a higher $\mathrm{GH}$ dose $[26,36]$. This scheme results in 4 categories of GH sensitivity: normal (sufficient response to lowest GH dose), moderate insensitivity (sufficient response to intermediate dose), modest insensitivity (sufficient response to highest dose), and (near-) complete insensitivity (no response to any dose). 
This minireview aims at discussing the differential diagnosis for a short child with low IGF-I and a normal GH peak in at least one GHST, in whom acquired causes of decreased serum IGF-I (e.g., malnutrition, hypothyroidism, psychosocial dwarfism, and anorexia nervosa) have been ruled out. In Critical Appraisal of the Diagnostic Value of GH Profiles and of the Validity of the Concept of GH Neurosecretory Dysfunction, we present a critical appraisal of the role of 12 - or 24 -h GH profiles in the diagnosis of short stature and of the concept of growth hormone neurosecretory dysfunction (GHND). In Genetic Conditions Associated with Normal GH Sensitivity, several genetic conditions associated with a normal GH sensitivity are discussed, in particular pathogenic GH1 and GHSR variants. Causes of GHI are reviewed in Conditions with Decreased GH Sensitivity. In Hypothetical Causes of Short Stature Associated with a Low Serum IGF-I and Normal Stimulated GH Peak, we speculate on some hypothetical causes.

\section{Critical Appraisal of the Diagnostic Value of GH Profiles and of the Validity of the Concept of GH Neurosecretory Dysfunction}

In the early 1970s, the use of a small portable continuous blood withdrawal system [37] enabled performing spontaneous $24-\mathrm{h} \mathrm{GH}$ profiles, either by the continuous withdrawal technique [37] or frequent sampling [38]. For a comparison of these methods, the reader is referred to [20]. The 24 -h GH profiles show a circadian rhythm (related to the sleep-wake cycle) and an ultradian rhythm regulated by the central nervous system and are also influenced by exercise, stress, and the daily feeding cycle [39]. A pilot study in short children suggested that some short children with normal GHST results might have a decreased spontaneous GH secretion [40]. Furthermore, a disturbed secretory pattern with decreased GH secretory spikes, both in frequency and amplitude, were observed as a result of cranial irradiation, first in rhesus monkeys [41] and later in children recovered from acute lymphatic leukaemia or brain tumours [42-47]. A later study suggested that a significant number of patients developed hypothalamic radiation-induced damage to the GHRH-secreting neurons, and secondary to this a decreased responsiveness to GHRH in the pituitary gland [48].

Theoretically, a spontaneous 24 -h GH profile would appear a better test to assess GH secretion. However, the taskforce of the Drug and Therapeutics, and Ethics Com- mittees of the Pediatric Endocrine Society felt that "any potential benefit of overnight GH sampling did not warrant the burden to patients" [6]. Still, in a 2002 European audit, routine assessment of spontaneous GH secretion was reported by 40 respondents (17\%) [25], and according to a recent audit in 8 European countries, 12 -h nocturnal GH profiles are still used in Germany and the UK [26]. In Sweden, clinicians currently have 2 options: a spontaneous 12-h GH night profile or a GHST (arginineinsulin tolerance test, AITT) preceded by a $3-\mathrm{h} \mathrm{GH}$ profile (to avoid false-positive test results) [24, 49, 50].

\section{Characteristics of 24-h GH Profiles in Healthy \\ Children}

Looking back at the 3 decades in which most scientific work was done on GH profiles in children (1980-2010), the different interpretations of the diagnostic value of $\mathrm{GH}$ profiles seem to be essentially based on different perceptions of the reference range of $\mathrm{GH}$ secretion in healthy children, the influence of limited sample sizes, the reproducibility, and the chosen outcome measure, including the role of the GH secretory pattern.

Determinants, Reference Range, and Sample Sizes

Essentially, spontaneous $\mathrm{GH}$ profiles can be used to assess the $\mathrm{GH}$ secretion pattern or the $\mathrm{GH}$ secretion rate. The major determinant of spontaneous $\mathrm{GH}$ secretion rate in healthy children is pubertal stage: GH secretion increases with advancing puberty, with a peak at Tanner stage 4 [17, 20, 51-55]. Further, mean night-time GH levels correlate inversely with BMI in both sexes $[53,55]$, in line with an inverse correlation between GH secretion rate per kg body mass and weight for height SDS in pubertal children [56]. Spontaneous GH secretion is positively correlated with height SDS [56] and height velocity [57].

Two groups of clinical investigators (headed by Bercu and Zadik, respectively) concluded that healthy controls and short children with normal height velocity had a $24-\mathrm{h}$ integrated concentration of GH (IC-GH) above 3.0 or 3.2 $\mu \mathrm{g} / \mathrm{L}$, respectively $[17,58,59]$. However, this conclusion was based on very few control subjects. Spiliotis et al. [58] coined the term GHND, defined by the following criteria: height less than first percentile; height velocity $\leq 4 \mathrm{~cm} /$ year; bone age $\geq 2$ years behind chronological age; normal findings from GHST (peak $>10 \mu \mathrm{g} / \mathrm{L}$ ); low somatomedinC (IGF-I) level; and abnormal 24-h GH secretory pattern. However, the number of prepubertal control children with short stature was only 9. In the follow-up study [59], it was an unreported fraction of 31 controls (short and 
normal stature) with a mean age of 13.2 years (range 5.017.9 years) and a Tanner stage range of $1-5$. In the study by Zadik et al. [17], 95\% of IC-GH values in all 119 children were above $3.2 \mu \mathrm{g} / \mathrm{L}$, but no information was provided on the percentage in the 36 prepubertal children.

Two other groups concluded that $24-\mathrm{h} \mathrm{GH}$ secretion in prepubertal controls is quite variable and overlaps with observations in children with GHD: the group headed by Albertsson-Wikland in Gothenburg (Sweden) [52] and Rose et al. at NIH (Bethesda, USA) [53, 60]. In 62 prepubertal children, mean 24 -h GH concentration was close to $2 \mu \mathrm{g} / \mathrm{L}$ [53]. Besides these 4 groups, $24-\mathrm{h}$ GH profiles were performed in several other centres such as London (Hindmarsh/Brook) and Tübingen (Bierich/Ranke).

\section{Reproducibility}

In 40 poorly growing children in whom a $\mathrm{GH}$ profile was performed twice within 4 weeks, the first and second IC-GH were highly correlated, but at the individual level, there were quite large differences [15]. In another study on 24 -h GH profiles in 9 children with a mean time interval of 1.5 years, the intra-individual reproducibility was rather poor: the difference in secretion ranged from $-31 \%$ to $+37 \%$, with a mean intra-individual coefficient of variance of $12 \%$. The changes in mean peak amplitudes between the repeated profiles showed a considerable interindividual variation between $-54 \%$ and $+38 \%$ (mean coefficient of variance 15\%) [61]. Similar results were obtained in other longitudinal studies [62, 63]. Albertsson-Wikland and Rosberg [20] concluded "that the reproducibility of repeated 24 -h profiles is nearly as low as the reproducibility of the $\mathrm{GH}$ response to repeated pharmacological tests for an individual child; if there are any differences, they are less pronounced for 24-h integrated concentrations than for the GH response to pharmacological tests" $[15,62,64]$.

\section{Choice of Outcome Measure}

A 24-h GH profile can be based on integrated (continuous) versus discrete sampling (usually at 20 -min intervals), and software programs generate a number of output variables $[20,52,65]$. For example, the Pulsar analyses with setting for $24-\mathrm{h} \mathrm{GH}$ curves generate data on overall mean; the maximal and minimal value; the mean of the calculated baseline; the number of peaks; the mean interpeak interval; the mean peak height, length, amplitude, and peak area; and the area under the curve above the zero level as well as above the calculated baseline [52]. The usual outcome measure is an indicator of the average $\mathrm{GH}$ concentration at all time points, such as the IC-GH, mean GH concentration, or area under the curve. However, in the construction of a prediction model for the growth response to recombinant human $\mathrm{GH}$ (rhGH) treatment, the highest GH peak (usually occurring at night) showed a slightly better correlation with the growth response than the area under the curve above baseline, estimated as roughly equivalent to the mean GH level [49, 66].

\section{Critical Appraisal of the Concept of GH}

Neurosecretory Dysfunction

Based on a pilot study on the IC-GH in short children [40] and the study on children with acute lymphatic leukaemia who underwent preventive irradiation [42], Spiliotis et al. [58] investigated 32 short children and 13 normal-stature controls. Of the short children, 16 were classified as GHD (GH peak $<10 \mu \mathrm{g} / \mathrm{L}$ in a GHST, mean $24-\mathrm{h}$ GH concentration $<0.6-3.3 \mu \mathrm{g} / \mathrm{L}$ ), 9 as controls (normal GH peaks after stimulation, mean $24-\mathrm{h} \mathrm{GH}$ concentration 3.1-12.2 $\mu \mathrm{g} / \mathrm{L}$ ), and 7 as GHND (normal GH peak in stimulation test, mean $\mathrm{GH}$ concentration $\leq 3 \mu \mathrm{g} / \mathrm{L}$ ). When one takes a closer look at the 7 patients with GHND, all were in Tanner stage 1, while this was only expected for 3 children aged 7.4, 11.6, and 12.5 years. The remaining 4 males (aged 14.8, 15.0, 15.0, and 15.5 years) had an extremely delayed puberty and bone age. It is noteworthy that the highest nocturnal GH peak was $\geq 10 \mu \mathrm{g} / \mathrm{L}$ in 6 out of 16 in the GHD group and in all members of the GHND group $(10-22 \mu \mathrm{g} / \mathrm{L})$. Treatment of the GHND patients with pituitary hGH $(3 \times /$ week) doubled height velocity, similar to the "GHD" patients.

In a follow-up study [59] on 73 patients ( $21 \mathrm{GHD}, 21$ GHND, 18 short controls, and 13 normal-stature controls), GHND was now formally defined as a mean serum 24-h GH concentration below $3.0 \mu \mathrm{g} / \mathrm{L}$, a normal response $(>10 \mu \mathrm{g} / \mathrm{L})$ to provocative testing, a low plasma IGF-I, and clinical features consistent with GHD. Again, in all children labelled GHND, the highest nocturnal GH concentration was $>10 \mu \mathrm{g} / \mathrm{L}$, close to the peak GH in the stimulation test [59]. Similar results were reported in 18 children with GHND [66]. GHND was also found in 3 out of 5 children with an empty sella [67].

In the meantime, Dr. Zadik had published similar data on IC-GH of 90 short children (19 GHD) compared with IC-GH from 46 children of normal stature. Mean IC-GH in children with GHD, short children with a normal GH peak in a GHST, and normal-stature controls was $1.6 \pm$ $0.6,3.8 \pm 2.3$, and $6.6 \pm 1.9 \mu \mathrm{g} / \mathrm{L}$, respectively. Forty-five percent of children with normal stimulated GH responses had an IC-GH within the range of values for the group
Wit/Joustra/Losekoot/van Duyvenvoorde/ de Bruin 
with GHD [68]. The incidence of GHND (IC-GH $<3.2$ $\mu \mathrm{g} / \mathrm{L}$ ) among children with a height SDS less than -2.5 without obvious underlying causes was estimated at $45 \%$ [69]. The authors also showed that differences in IC-GH between normally growing and poorly growing children are due to a lower amplitude of peaks during the daytime hours [70] and that rhGH administration did not suppress endogenous $\mathrm{GH}$ secretion in patients with GHND [71]. This was later confirmed by Lundberg et al. [72], who showed spontaneous $\mathrm{GH}$ peaks for $4 \mathrm{~h}$ following sc $\mathrm{GH}$ injections. The growth response of boys with GHND after 4 years of GH treatment was similar to that of children with classical GHD [73], and GH treatment had a positive effect on adult height [74]. Interestingly, at retesting after 3-4 years, 3 children with GHND showed a subnormal GH response to stimulation, suggesting that in some patients, a regulatory defect in neurosecretion is noted first, while at a later stage, the response of the pituitary to stimulation is lost [75].

We believe that there are several reasons to challenge the claims of these 2 groups on the existence of the hypothetical GHND. First, the distribution of the mean GH concentration of healthy children is much wider than the authors' estimations, probably associated with the limited number of prepubertal controls. The 3.0-3.2 $\mu \mathrm{g} / \mathrm{L}$ cutoff for IC-GH is too high, according to observations in larger groups of children $[52,53]$. Second, the authors probably overestimated the reproducibility. Third, the authors have not given proper attention to an alternative outcome marker that may be at least as important, that is, the highest spontaneous GH peak [49], which was $>10 \mu \mathrm{g} / \mathrm{L}$ in all cases $[58,59]$. In addition, the growth response to hGH treatment in children labelled as GHND does not support the concept of a separate GHND condition either. Bercu and colleagues showed that the response to pituitary hGH administration $(0.15-0.30 \mathrm{mg} / \mathrm{kg} \cdot$ week, $3-7$ injections/ week) was similar in short children regardless of provoked and/or endogenous GH secretory dynamics [7678].

Does this mean that "GHND" does not exist? We believe there may be 2 examples of its existence in special pathological conditions. First, the robust data on children who received cranial irradiation indicate a decreased spontaneous GH secretion and disturbed GH secretion pattern, as mentioned above [42-47]. Second, there is a clinical syndrome in which spontaneous GH secretion and serum IGF-I are usually decreased, while GHST results are often normal: Prader-Willi syndrome [79, 80]. For example, in 23 non-obese children, the mean stimulated GH peak was approximately $6 \mu \mathrm{g} / \mathrm{L}$ (implying that

IGF-I Deficiency in Short Stature approximately $40 \%$ would have a peak of $>7 \mu \mathrm{g} / \mathrm{L}), 4$ times lower than healthy controls [81], and mean 24-h $\mathrm{GH}$ concentration was $0.7 \mu \mathrm{g} / \mathrm{L}$ [82], suggesting that a GHST is not an appropriate test in such children. In a recent Dutch study, mean serum IGF-I in childhood was -1.7 SDS, suggesting that IGF-I was less than -2 SDS in about $40 \%$ of cases. Interestingly, $\mathrm{GH}$ secretion appears to increase by age in this syndrome: both serum IGF-I and IGFBP-3 normalized in GH-treated young adults, and none of the patients met the criteria for adult GHD [83].

Besides these 2 examples, the use of 2 different tools for assessing GH secretion (a GH profile and a GHST) automatically leads to groups, which are labelled deficient with one tool and not with the other. This will be further discussed in the following sections.

\section{Critical Appraisal of the Diagnostic Value of \\ Spontaneous GH Secretion}

In contrast with the 2 groups of clinical scientists that assumed healthy children have an IC-GH above 3.0-3.2 $\mu \mathrm{g} / \mathrm{L}$ (see Critical Appraisal of the Concept of GH Neurosecretory Dysfunction), 2 other groups emphasized the wider range of $\mathrm{GH}$ secretion and the considerable overlap with children with GHD $[52,53]$. However, the conclusions of the 2 latter groups differed. Rose et al. [84] concluded that "standard GH stimulation tests, despite their limitations, remain the best definitive test of GH secretion," which ended the NIH programme. In contrast, the group of Albertsson-Wikland and her successors consider a 12-h GH profile superior to a GHST. As mentioned earlier, in Sweden such profile or a GHST preceded by a 3-h GH profile to control for refractoriness are currently used in Sweden (personal communication Drs. Albertsson-Wikland and Kriström).

The current approach of this Swedish group is based on a series of studies between the early 1980s and 2007, in which spontaneous $\mathrm{GH}$ secretion was used as a potential predictor in the growth "prediction model." The Gothenburg prediction models were designed to predict the growth response in the first 2 years of GH treatment (expressed as the change in height SDS) in short children irrespective of GH secretion, so including GHD and idiopathic short stature (ISS). In addition to data included into the basic model data (auxological data from the year before the start of GH treatment and parental heights), the other 4 models included either growth data from the first 2 years of life, serum IGF-I, GH secretion estimated during a provocation test (AITT) or a spontaneous GH secretion profile [49]. While the GH peak during the AITT or IGF-I SDS were predictive (though at an inter- 
mediate magnitude, similar to the predictive value of early growth), the maximum $\mathrm{GH}$ peak over $24 \mathrm{~h}\left(\mathrm{GH}_{\max } 24 \mathrm{~h}\right)$ was the most informative variable, closely followed by the area under the curve above baseline. Adding early growth variables and $\mathrm{GH}_{\max } 24 \mathrm{~h}$ to the basic model resulted in the model with the best accuracy (narrower prediction interval), considerably better than if the GH peak during the AITT provocation tests or IGF-I SDS was added [49]. A further refinement of the prediction model, including data from children born prematurely and/or small for gestational age (SGA), was published in 2007 [85].

The original prediction model [49] was used to test the hypothesis whether individualized GH doses, based on variation in $\mathrm{GH}$ responsiveness estimated by the prediction model, reduced variability in growth response around a preset height target compared with a standardized weight-based dose, in 153 short prepubertal children who were tested with a $24-\mathrm{h}$ GH profile as well as an AITT. If the highest GH peak from the 24 -h profile was used instead of the GH peak in the AITT, the diagnosis was switched from isolated GHD to ISS in $30 \%$ of cases [50]. Individualized GH doses during catch-up growth indeed reduced the proportion of unexpectedly good and poor responders around a predefined individual growth target, while mean growth responses were equal [50].

Several studies have assessed to which extent a shorter interval than $24 \mathrm{~h}$ would generate similarly useful information. The highest $\mathrm{GH}$ peak obtained during a sampling period limited to $12 \mathrm{~h}$ at night resulted in an acceptable prediction level for $97 \%$ of the children and was still a better predictor of the growth response than the GH peak during an AITT or IGF-I levels when used in the prediction models [86]. Shortening the time interval to $6 \mathrm{~h}$ resulted in a considerable loss of accuracy $[86,87]$. Technical aspects of the analysis of $24-\mathrm{h} \mathrm{GH}$ profiles (secretion rate and pattern) were described in detail $[56,65]$ as well as the influence of standard preparations, GH isoforms, assay characteristics, GH-binding protein (GHBP) [22] and 24-h profiles in short children born SGA [88].

In the discussion about whether one should use the GH peak in a GHST or an indicator of spontaneous GH secretion (or both), there is a tension between theoretical and pragmatic arguments. In theory, a 12- or 24-h GH profile should be a better indicator of spontaneous $\mathrm{GH}$ secretion than the GH peak in a GHST, considering all its drawbacks [10]. However, the burden to the patient and the financial and logistical burden to the health and hospital system are considered larger. We assume that these are the main reasons that presently $\mathrm{GH}$ profiles are used only in few centres.

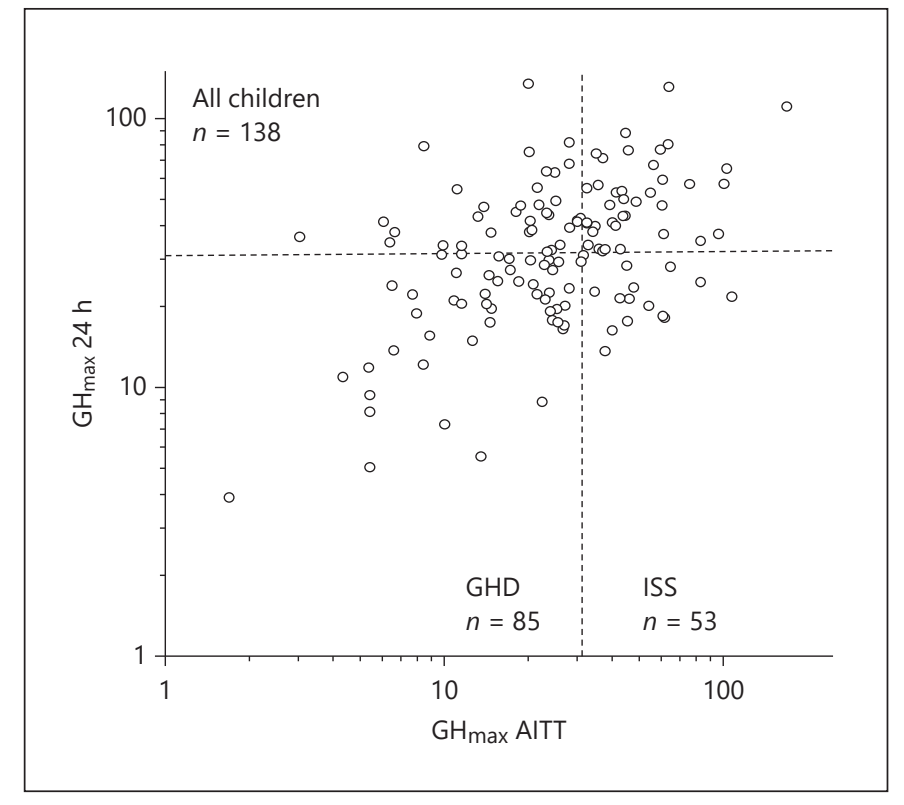

Fig. 1. Scatterplot of results of $\mathrm{GH}_{\max } 24 \mathrm{~h}$ (in $\mathrm{mU} / \mathrm{L}, y$ axis) versus $\mathrm{GH}_{\max }$ AITT (in mU/L, $x$ axis). Both for the GH profile and AITT, polyclonal antibodies and WHO IRP 80/505 standard were used. Stippled lines indicate a cutoff of $32 \mathrm{mU} / \mathrm{L}$ (equivalent to $10 \mu \mathrm{g} / \mathrm{L}$ with the respective assay). The data are derived from AlbertssonWikland et al. [49]. The figure was first published in the $\mathrm{PhD}$ thesis of Dr. Kristrom, Umeå University Medical Dissertations, ISBN 91-7191-611-3, and kindly provided by Dr. Kristrom. GH, growth hormone; $\mathrm{GH}_{\max } 24 \mathrm{~h}$, highest $\mathrm{GH}$ peak in a 24 - $\mathrm{h}$ GH profile; $\mathrm{GH}_{\max }$ AITT, GH peak in an arginine-insulin tolerance test.

We believe that for centres where $\mathrm{GH}$ profiles are not done, it is still helpful to be informed about observations in centres performing 24 -h GH profile as well as a GHST. First, it is informative to see the scatterplot of the highest GH peak in the 24 -h GH profile $\left(\mathrm{GH}_{\max } 24 \mathrm{~h}\right)$ versus the GH peak observed in the AITT, as shown in Figure 1, kindly provided by Drs. Berit Kristrom and AlbertssonWikland, Umea and Gothenburg, Sweden (data derived from [49] and used in [50]). As expected, there is a positive correlation, but at any cutoff limit, there are children who could be diagnosed as GHD or ISS depending on whether the clinician chooses the $\mathrm{GH}_{\max } 24 \mathrm{~h}$ or stimulated $\mathrm{GH}$ peak as diagnostic criterion.

In a recent retrospective study from Sweden on 102 short children [24], a highly variable frequency (6-42\%) of divergent results from AITTs and nocturnal spontaneous GH tests was found, which was significantly associated with cutoff values applied. At a cutoff of $7 \mu \mathrm{g} / \mathrm{L}, 57 \%$ had normal results on both tests, $18 \%$ pathological results on both tests, $7 \%$ pathological results on the nocturnal
Wit/Joustra/Losekoot/van Duyvenvoorde/ de Bruin 
test only, and $19 \%$ pathological results on the stimulation test only. At a cutoff of $10 \mu \mathrm{g} / \mathrm{L}$, these percentages were $34,37,11$, and $18 \%$, respectively [24]. These results show that a potential advantage of this strategy is that the 12- or 24-h GH profile can reduce the number of false-positive tests of GHSTs by approximately $20 \%$. The authors provided evidence that this discrepancy is frequently caused by the refractory interval of $3 \mathrm{~h}$ [23]. At the same time, in $7 \%$ of short children, a low nocturnal GH peak is found in contrast to a normal GH peak in a GHST [24], who may respond positively to $\mathrm{GH}$ treatment [24]. Interestingly, a similar percentage was found in Tübingen (Germany), where $9 \%$ of non-acquired cases with GHD were labelled GHND [89]. While it is tempting to assume that these cases indeed represent GHND, one should still bear in mind the suboptimal reproducibility of $\mathrm{GH}$ profiles as well as GHSTs [61, 63]. A reassuring observation is that the stimulated $\mathrm{GH}$ peak can be reliably replaced by the 12-h GH peak with similar accuracy in the KIGS prediction model [90].

\section{Conclusion}

If for logistical or financial reasons, no GH profile for a short child with a low serum IGF-I and normal GHST can be performed, the clinician can choose among 3 options. First, one can decide to prescribe rhGH as a therapeutic trial, if national regulations permit, for example, in Sweden $[91,92]$ and the USA. Second, one can conclude that the child is not $\mathrm{GH}$ deficient and abstain from any treatment. A third option was taken by the paediatric endocrine community in the Netherlands, where an IGFGT is performed in such cases; if the IGF-I response is sufficient on any dose, a 1-year trial with rhGH therapy is allowed by the National Committee, which may be continued if the growth response is appropriate [26].

\section{Genetic Conditions Associated with Normal GH Sensitivity}

Kowarski Syndrome (Bioinactive GH Protein, Caused by a Pathogenic GH1 Variant)

While in the majority of IGF-I-deficient children with a normal result of the GHST or spontaneous GH secretion, the cause may be associated with the inaccuracy of both tests, there can also be a genetic origin. The 2 main candidate genes for such presentation include $G H 1$, encoding the pituitary GH protein, and GHSR, encoding the $\mathrm{GH}$ secretagogue receptor (ghrelin receptor).
Most pathogenic variants of $\mathrm{GH} 1$ cause a form of congenital GHD, either with an autosomal recessive inheritance pattern (isolated GHD types 1A [MIM \#262400] or 1B [MIM \#612781]) or an autosomal dominant inheritance (isolated GHD type 2, MIM \#173100) [93-95]. Patients with isolated GHD type 1A have severe growth retardation, which usually becomes apparent in the first 6 months of life and is caused by homozygous or compound heterozygous deletions, insertions, frameshift, or nonsense variants in GH1. In patients with isolated GHD type $1 \mathrm{~B}$, serum $\mathrm{GH}$ levels are low but detectable and the phenotype is more heterogeneous. In most cases, homozygous or compound heterozygous splice site, frameshift, nonsense, or missense variants in GH1 or GHRHR (encoding the GH-releasing hormone receptor) are found. In isolated GHD type 2, with autosomal dominant inheritance, GH secretion is very low but usually still detectable, and in most cases, it is associated with heterozygous intronic deletions, missense, splice site, or splice enhancer variants in $G H 1[94,96,97]$.

Kowarski syndrome (MIM \#262650) was named after the American paediatric endocrinologist who studied 2 unrelated boys with growth retardation and delayed bone ages, presenting with a normal immunoreactive GH peak after stimulation, but low levels of serum IGF-I [98]. Their growth and serum IGF-I responded positively to $\mathrm{GH}$ administration. At that time, further genetic assessment could not be performed. In the following years, several patients with similar clinical features were reported $[29,99-101]$.

Proof of the existence of a clinical syndrome caused by a bioinactive GH protein was provided in 1996-1997 [102-104] (Table 1). The first case with clinical and laboratory features of severe GHD, but with an increased GH peak in an insulin tolerance test $(38 \mu \mathrm{g} / \mathrm{L})$, was reported to carry a p.(Arg77Cys) variant (c.307C $>$ T, p.(Arg103Cys) according to the HGVS nomenclature) [102, $103,105]$. The mutant GH did not stimulate tyrosine phosphorylation in IM-9 cells and also inhibited the ability of wild-type GH (wt-GH) to stimulate tyrosine phosphorylation, thus having a dominant negative action. The affinity of the mutant GH for GHBP was significantly higher than that of wt-GH. Interestingly and unexplained, in the proband's father carrying the same variant, isoelectric focussing revealed that the father's serum contained a single $\mathrm{GH}$ peak corresponding to wt-GH.

The second case with a milder phenotype was reported to carry a heterozygous p.(Asp112Gly) variant (HGVS c.413A>G, p.(Asp138Gly)) [104]. The locus of this variant was found within site 2 of the $\mathrm{GH}$ molecule in binding 
Table 1. Genetic, clinical, and biochemical characteristics of patients with bioinactive GH syndrome, sorted according to gene position

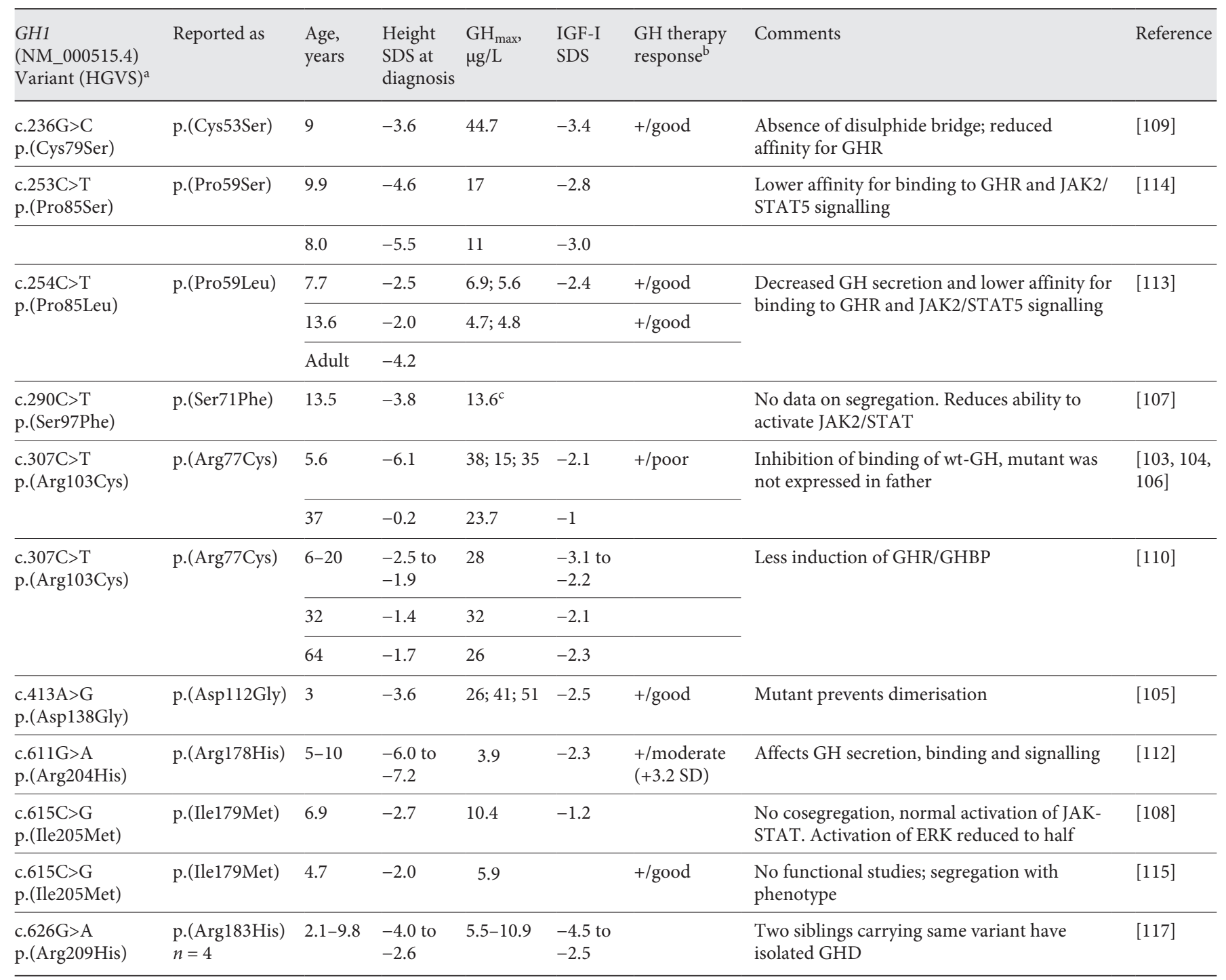

Adapted from [95, 96]. Compared with our previous publication [96], 2 variants, p.(Ser134Arg) and p.(Thr201Ala), were omitted, because these were GH deficient. GH, growth hormone; IGF-I, insulin-like growth factor I; SDS, standard deviation score; GHBP, GH-binding protein; GHD, growth hormone deficiency. ${ }^{a}$ The transcript that was used for HGVS nomenclature was NM_000515.4, and the protein reference sequence was NP_000506.2. The c. denotes nucleotide position on cDNA with the A of the translation start site (ATG) of the cDNA numbered $+1 .{ }^{b}$ A positive growth response is indicated as ".+ " cThe GH peak was reported as $27.2 \mathrm{mU} / \mathrm{L}$, at that time equivalent to $13.6 \mu \mathrm{g} / \mathrm{L}$.

with the GH receptor and GHBP, and the expressed recombinant mutant $\mathrm{GH}$ tended to form a 1:1 instead of the 1:2 GH-GHBP complex normally produced by wt-GH. The authors concluded that this variant molecule is bioinactive by preventing dimerisation of the GH receptor. After these seminal papers, several more cases have been reported, and the clinical and laboratory data of all presently known GH1 mutations associated with bioinactive GH syndrome are shown in Table 1 [102-114].
In an interesting study on children with short stature, reduced height velocity, and bone age delay [106] and a cohort of children with severe GHD, there was one child with a normal GH peak in a GHST and his short mother who carried a heterozygous GH1 variant reported as p.(Ser71Phe) (HGVS c.290C > T, p.(Ser97Phe)). Although segregation of the variant was not confirmed and although no data were reported on serum IGF-I and the growth response to $\mathrm{GH}$, in vitro studies showed that the 
variant reduced the ability to activate the JAK2/STAT signalling pathway [106]. Although the authors did not identify this child as Kowarski syndrome, this diagnosis appears likely in this case.

The pathogenicity of the variant, c.615C>G, p.(Ile205Met), reported by Lewis et al. [107] is uncertain. Arguments in favour include evolutionary conservation of the residue and evidence from molecular modelling, but arguments against are the absence of cosegregation with short stature in the family, the similar degree of resistance manifested by the $\mathrm{GH}$ variant to proteolytic cleavage as compared with wt-GH, normal binding to the GH receptor, and the normal STAT5 activation. The minimum allele frequency of this variant is $0.04 \%$, and it was later reported in a child with GHD [114].

In the following years, several cases with bioinactive GH1 variants were reported by the group of Petkovic/ Mullis from Bern (Switzerland). The p.(Cys79Ser) variant was bioinactive at the physiological range, showing that the disulphide bridge Cys-53 to Cys-163 is required for mediating the biological effects of GH [108]. Studies on a family carrying the same variant, as previously reported by Takahashi et al., p.(Arg77Cys), showed a reduced capability of the variant to induce the GHR/GHBP gene transcription rate when compared with wt-GH [109]. In 2010 , they described a patient suffering from short stature caused by a heterozygous $G H 1$ alteration (reported as p.(Arg178His)), which not only affected GH secretion (consistent with isolated GHD type 2) but also GH binding and signalling [111]. One year earlier, a child with isolated GHD type 2 had been reported with the same variant [110]. A similar alteration of secretion as well as bioactivity was observed in a patient carrying a previously reported variant, p.(Pro59Leu) [112]. Interestingly, another variant at the same position, p.(Pro59Ser), led to a high secretion of GH-P59S and had also an impact on GHR binding and signalling, which may alter GHR responsiveness to wt-GH [113].

While Kowarski syndrome is characterized by a normal immunoassayable GH secretion in contrast to a low bioactivity, a Japanese case report showed that a GH1 variant can also show undetectable serum $\mathrm{GH}$ values during insulin, clonidine, and GH-releasing hormone provocation tests, whereas urinary GH excretion was within the normal range [115]. Genetic testing showed compound heterozygosity in the $\mathrm{GH} 1$ gene for a missense variant, p.(Asp116Glu), of paternal origin and a frameshift variant, p.(Gln68fs*106), of maternal origin. Genotype-phenotype correlations in this family and in vitro functional studies indicated that the p.(Asp116Glu)-GH could be measured with another $\mathrm{GH}$ kit and had a reduced in vivo bioactivity. The p.(Gln68fs*106) yielded no GH protein. Finally, a recent paper in a large extended family showed that a heterozygous $G H 1$ variant known to be associated with type II GHD (c.626G > A, p.(Arg209His), previously reported as p.(Arg183His)), can in some individuals also lead to a presentation of short stature with a normal GHST and good growth response to rhGH, suggestive for Kowarski syndrome [116].

In conclusion, there is no doubt that some heterozygous $\mathrm{GH} 1$ variants encode variant $\mathrm{GH}$ molecules that are bioinactive and can have a dominant negative effect. In a few cases, GH secretion is also affected, at first sight suspected for isolated GHD type 2, and in other cases, it may be combined with partial GHI. The syndrome is characterized by clinical features and low serum IGF-I and IGFBP-3 concentrations compatible with GHD, in contrast with a normal or even increased serum GH response to a GHST, and the growth response to rhGH treatment in terms of growth and serum IGF-I is generally appropriate.

\section{Ghrelin Insensitivity (GHSR Defects)}

In 1999, ghrelin was isolated as the endogenous ligand for the receptor GHSR1A (encoded by GHSR) and for its ability to stimulate GH secretion [117]. In addition to a direct stimulatory effect on the pituitary gland, ghrelin was shown to amplify GH secretion by modulation of the activity of GHRH neurons [118]. Consistent with the physiological actions of acyl-ghrelin on energy homeostasis and GH secretion, animals with a disruption in GHSR display a leaner and shorter phenotype and have reduced IGF-I levels [119], supporting a role of the GHSR in body growth [118]. Two GHSR isoforms have been identified $[120,121]$; the primary GHSR1 A product contains 7 transmembrane domains, whereas GHSR1B is an inactive form with 5 transmembrane domains [122].

Although "isolated partial GHD" due to a GHSR variant is a registered syndrome (MIM \#615925), only few cases have been reported, the clinical and laboratory phenotype is remarkably diverse, and cosegregation of the genotype with short stature is little convincing $[123,124]$. A summary of reported cases is shown in Table 2. GHSR variants have also been associated with obesity [125].

The first case was found in a genetic analysis in 43 children with "short normal stature," probably equivalent to ISS. The novel heterozygous genetic variant c. $837 \mathrm{C}>\mathrm{A}$, p.(Phe279Leu), led to the exchange of a highly conserved amino acid in the sixth transmembrane domain of GHSR [125], which had been previously described to exert de- 
Table 2. Selected characteristics of patients with GHSR (NM_198407.2) variants, sorted according to year of publication

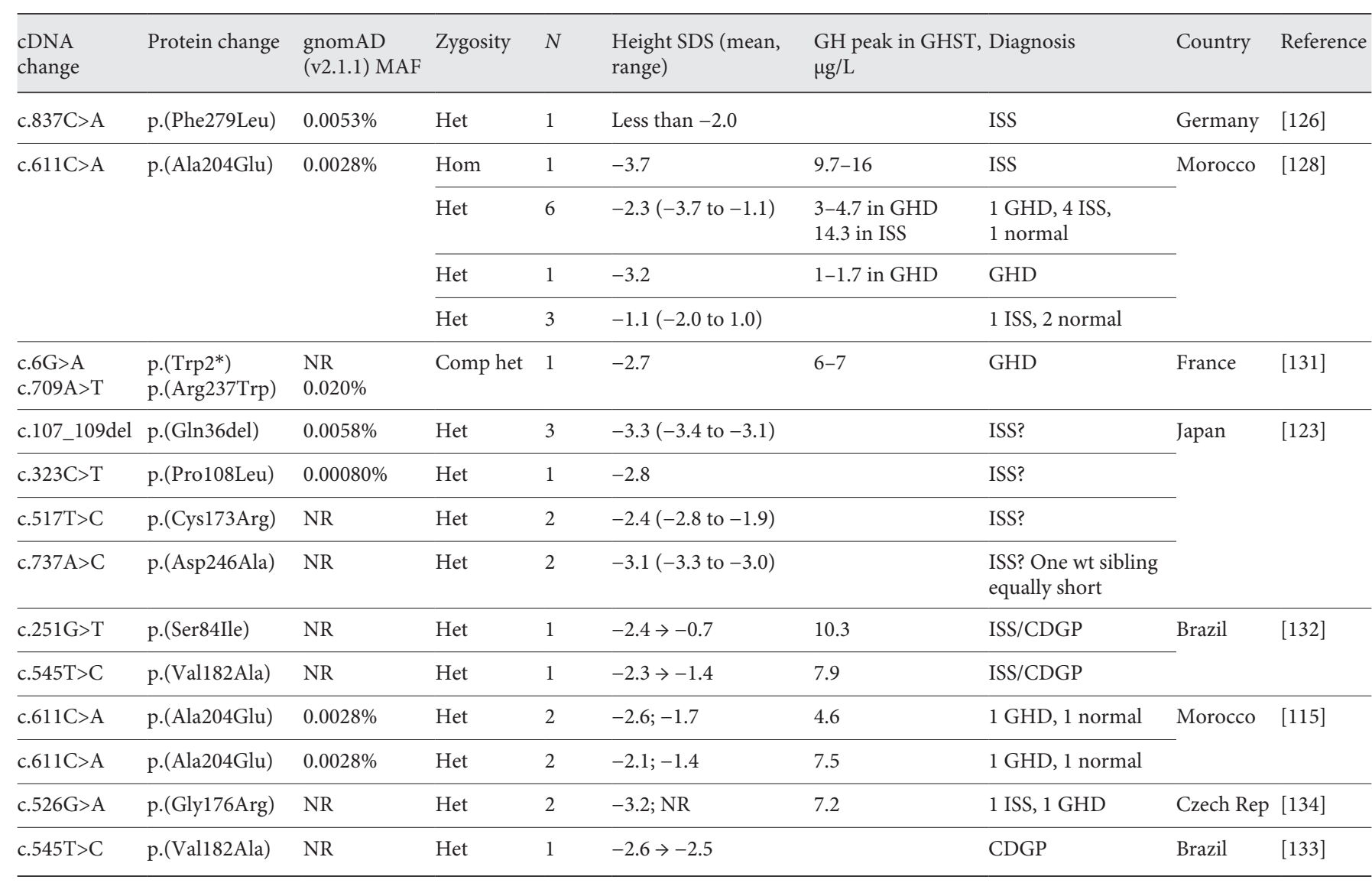

CDGP, constitutional delay of growth and puberty; Comp het, compound heterozygous; gnomAD, Genome Aggregation Database; GHD, growth hormone deficiency; GHST, growth hormone stimulation test; Het, heterozygous; Hom, homozygous; ISS, idiopathic short stature; MAF, minor allele frequency; NR, not reported; SDS, standard deviation score; Rep, Republic; wt, wild type; $\rightarrow$, longitudinal data on height SDS.

creased specific binding properties for a GHSR agonist [126]. Further support for the pathogenicity of the variant was offered by the observation that the variant was inherited via the mother with short stature [125].

The second variant, c.611C>A, p.(Ala204Glu), was reported in 2 unrelated families from Morocco [127]. In family 1 , the proband (with a homozygous mutation) was very short (height -3.7 SDS) and had a normal GHST result. Of the 5 relatives heterozygous for the variant, the parents and 2 siblings were short, but 1 sibling had a normal stature. In family 2 , the heterozygous proband had isolated GHD (height $-3.2 \mathrm{SDS}$ ), but only the parent carrying the GHSR variant was short, while height of the 2 siblings (also carriers) was well within the reference range, one even +1.0 SDS. The authors suggested that this variant is dominant with a penetrance of $66 \%$. In vitro, the variant resulted in decreased cell surface expression of the receptor and selectively impaired the constitutive activity of the GHSR, while preserving its ability to respond to ghrelin [127]. The high basal activity of GHSR has shown to be of physiological importance in regulating both $\mathrm{GH}$ secretion and food intake, as demonstrated with in vivo experiments (reviewed in Wang and Tao [128]). The functional effect of the variant was recently confirmed in a GHSR-Ala203Glu mutant mouse model, which also showed decreased body weight, body length, and femur length at 1 year of age [129].

In a later publication by the French group [130], a boy with partial isolated GHD (height -2.7 SDS) was found to be compound heterozygous for 2 GHSR variants. The 2 heterozygous carriers of the $\mathrm{p}$. $(\operatorname{Trp} 2 *)$ nonsense variant (mother and 1 sibling, height -1.3 and -1.7 SDS, respectively) tended to be shorter than the carrier of the $\mathrm{p}$. (Arg237Trp) missense variant (father, height -0.6 SDS) 
and the sibling carrying wt-GHSR (height -0.2 SDS). In vitro experiments showed that the $\mathrm{p}$.(Arg237Trp) variant would result in a partial loss of constitutive activity of the receptor, whereas both its ability to respond to ghrelin and its cell surface expression were preserved.

A Japanese group performed mutational screening of GHSR in 127 unrelated Japanese patients diagnosed with either isolated GHD $(n=14)$ or ISS $(n=113)$, and 188 control subjects were analysed for the presence of these mutations [122]. For 4 variants, the clinical features and functional studies (loss of constitutive activity) made it likely that the GHSR variants may cause short stature. The heterozygous p.(Gln36del) variant was detected in 3 patients as well as 1 control and the 3 other heterozygous variants, p.(Pro108Leu), p.(Cys173Arg), and p.(Asp246$\mathrm{Ala})$, were only found in a single patient each. However, data on cosegregation were limited, and in several cases not confirmatory. For the first patient with the p.(Gln$36 \mathrm{del}$ ) variant, no genetic data on the normal-stature parents were available, the parent of the second patient carrying this variant had a completely normal height $(0.0$ SDS), and clinical or genetic data were not available for the third patient. For the p.(Pro108Leu) variant, both parents had normal stature and their DNA was not tested. The parent and sibling carrying the variant encountered in the third patient p.(Cys173Arg) had a height of -1.9 SDS and -0.5 SDS, respectively. The proband and his mother carrying the p.(Asp246Ala) variant had a similar height SDS ( -3.3 and -3.0 SDS, respectively), but the sibling carrying the wt genotype was equally short (-3.1 SDS) [122].

In a Brazilian study, the GHSR coding region was directly sequenced in 96 independent patients with ISS (31 of them with constitutional delay of growth and puberty [CDGP]), 150 adults, and 197 children with normal stature [131]. Two short girls with CDGP who reached a normal adult height were found to carry a pathogenic variant, showing a decrease in basal receptor activity, in part explained by a reduction in cell surface expression. The p.(Ser84Ile) variant was not inherited via the mother, and no genetic analysis could be performed in the father. Notably, the 2 siblings who had normal stature and puberty were also heterozygous for the same variant. The father and sister of the girl carrying the p.(Val182Ala) variant were also carriers, and their growth and puberty patterns were compatible with CDGP. Her sister was treated with rhGH for GHD (maximum GH peak at stimulation test of $1.8 \mu \mathrm{g} / \mathrm{L}$ ) [131]. In a recent paper [132], an unrelated proband carrying this same variant was reported, with a height of -2.5 SDS at a relatively late pubertal onset of 13.5 years, with a bone age delay of 3 years [131].

IGF-I Deficiency in Short Stature
In a cohort of 46 Moroccan index cases with isolated GHD, the same GHSR variant, as previously reported, p.(Ala204Glu) [127], was detected in 2 children from 2 families, but in each family, this variant was also present in 1 sibling with normal height [114]. A child with severe GHD carried a novel variant, p.(Ala358Thr), inherited from his father with a height of -2.2 SDS. Though the alanine residue at codon 358 is conserved among mammalian species, the p.(Ala358Thr) variant was reported as a rare polymorphism [131] and is now listed as singlenucleotide polymorphism (SNP, rs150344113) with a frequency of 0.6 and $1.7 \%$ in American multi-ethnic (dbSNP) and African American (Exome Variant Server) cohorts, respectively. Finally, in a study on genetic testing of children with familial short stature, a heterozygous GHSR variant, p.(Gly176Arg), was found in an SGA born child with borderline GHD and limb shortening, as well as in his younger brother born appropriate for gestational age diagnosed with GHD [133].

Besides these case reports, it is important to note that in another cohort of short children, no pathogenic GHSR variants were found [134]. As applies to most scientific information, one can expect that there is a publication bias, because negative findings are not likely to be published. In our Laboratory for Diagnostic Genome Analysis, we detected 8 GHSR variants in 9 unrelated children out of 1,698 patients referred for genetic testing by next generation sequencing for short stature and/or skeletal dysplasia (0.5\%). Three variants were previously reported as pathogenic (2x c.611C>A p.(Ala204Glu); c.709A $>\mathrm{T}$ p.(Arg237Trp); and c.837C >A p.(Phe279Leu)) [125, 127, $130,135]$. The other 5 variants included 1 likely pathogenic truncating variant and 4 missense variants of uncertain significance (Drs. Losekoot and Van Duyvenvoorde, personal communication).

An indirect indication that GHSR variants may be associated with height is the significant association of GHSR polymorphisms with height in genome-wide association studies [136-138]. However, in another study, common variation in GHSR was not associated with body size [139]. In a study aimed at identifying genetic polymorphisms, which could serve as predictive markers of response to rhGH therapy, no such marker in GHSR was found [140]. In contrast, body length and weight of goats and pigs were significantly higher in animals carrying a GHSR polymorphism [141, 142].

In theory, a diminished function of the ghrelin receptor may occur not only as a result of a pathogenic GHSR variant but also because of a genetic abnormality of a regulator of GHSR expression. A recent paper reported that 
mice with a reduced Reck expression or with induced Reck deficiency from 10 days after birth showed decreases in body size and plasma levels of IGF-I. Reck is a tumour suppressor gene encoding reversion-inducing cysteine-rich protein with Kazal motifs (Reck), a membraneanchored protease regulator expressed in multiple tissues in mouse embryos. In postnatal Reck-/- mice, immunoreactivity of GH was greatly reduced, while GHSR and GHRH receptor immunoreactivity was decreased, although their mRNAs were increased [143].

In conclusion, arguments in favour of the hypothesis that GHSR variants are associated with short stature and CDGP are the various case reports, GWAS studies, functional data on decreased constitutive action of GHSR, and the knock-out mice studies. Arguments against include the variability of clinical phenotypes (GHD, ISS, or CDGP) and circulating IGF-I concentrations, incomplete segregation of the variations with the phenotype (normal stature in some carriers and short stature in parents or siblings with a wt genotype), and potential publication bias, in line with our previous considerations $[123,124]$.

\section{Other Suggested Mechanisms of a Diminished Action of $G H$}

There are a few other potential medical conditions for which the evidence on diminished GH action is weak. These will be discussed in the following paragraphs.

\section{Abnormal Composition of Secreted and Circulating $\mathrm{GH}$ Isoproteins}

Human GH isolated and secreted from the pituitary gland is not a single protein but rather a mixture of variants (isoproteins) differing in amino acid sequence, posttranslational modified forms, and fragments [144]. The major component $(22 \mathrm{kDa}, \mathrm{GH}$ molecule with a molecular weight of $22 \mathrm{kDa}$ [22K-GH]) is a single-chain polypeptide containing 191 amino acids and 2 intra-chain disulphide bridges, synthesized and stored in granules of specific acidophilic cells of the anterior pituitary [145]. According to an analysis of the approximate mean distribution of pituitary GH isoforms in human blood 15-30 min after a secretory pulse, $45 \%$ consists of $22 \mathrm{~K}-\mathrm{GH}$, half of which is bound to high-affinity GHBP [144]. The second main $\mathrm{GH}$ isoform (20K-GH), derived from GH1 by alternative mRNA splicing, has a structure analogous to $22 \mathrm{~K}-\mathrm{GH}$, except for the deletion of internal residues 32 46. It has 176 amino acids and a molecular mass of approximately $20 \mathrm{kDa}$ [146]. Five percent of the secretory pulse consists of $\mathrm{GH}$ molecule with a molecular weight of $20 \mathrm{kDa}$ (20K-GH) [144]. Acidic GH (desamido-, acylated, and glycosylated $\mathrm{GH}$ ) occupies $5 \%$ of the secretory pulse. Other components of the secretory pulse include 3 classes of dimeric GH $(22 \mathrm{~K} 20 \%, 20 \mathrm{~K} 5 \%$, and acidic GH dimers $2 \%)$ and 3 classes of oligomeric GH (22K 10\%, 20K $2 \%$, and acidic GH dimers 2\%) [144]. A third isoform, arising from skipping of exon 3 and lacking amino acid residues 32-71, was proposed as an additional GH variant (17.5K-GH) [147] but is not expressed in significant amounts under normal conditions [144].

In initial studies, various isoforms appeared to show differences in bioactivity. For example, 20K-GH was reported to lack insulin-like effects and have diminished diabetogenic activity [148]. However, subsequent studies yielded conflicting information, probably in part due to species differences. In humans, the somatogenic activity of $20 \mathrm{~K}-\mathrm{GH}$ appears qualitatively similar and quantitatively equivalent to that of $22 \mathrm{~K}-\mathrm{GH}$ [144]. However, the bioactivity of naturally occurring $\mathrm{GH}$ oligomers compared to monomeric $22 \mathrm{~K}-\mathrm{GH}$ ranges from moderately reduced to full bioactivity [144].

Regarding immunoreactivity, the heterogeneity of GH is the main cause of the disparities of GH results obtained among assays and laboratories, particularly with the modern specific monoclonal assays [149]. Furthermore, the plasma half-life of endogenous $20 \mathrm{~K}-\mathrm{GH}$ and of monomeric, dimeric, and oligomeric $\mathrm{GH}$ is longer than that of $22 \mathrm{~K}-\mathrm{GH}$ [150]. The picture is complicated further in the circulation, where $\mathrm{GH}$ binds to $2 \mathrm{GHBP}$, each with different affinities for the GH isoforms.

There are 2 papers suggesting that an abnormal composition of GH isoproteins may cause short stature. In the first case report [151], a 14-year-old boy showed a growth pattern consistent with GHD, normal GH peaks to GHSTs, and an excellent growth response to GH administration. Plasma somatomedin $\mathrm{C}$ level (the previous name for IGF-I) was interpreted as normal $(1.7 \mathrm{U} / \mathrm{mL}$, reference $0.4-4.5 \mathrm{U} / \mathrm{mL}$ for age). The ratio of radioreceptor-assayable to radioimmunoassayable $\mathrm{GH}$ was decreased, as well as the biological activity. When analysed by column chromatography, most of the immunoreactive GH migrated as approximately $85 \mathrm{kDa}$ ("big-big") and 45 $\mathrm{kDa}$ ("big") species, and these GH polymers constituted $60-90 \%$ of all immunoreactive material [151]. At the time, the normal quantity of tetramers and dimers in plasma was estimated at 14-39\% [152], in later studies slightly higher (41\%) [144]. Furthermore, in the patient, almost all polymers were resistant to conversion by urea. The authors concluded that the patient's short stature was due to an abnormal structure of his endogenous GH molecule. Our present interpretation is that the normal so-
92

Horm Res Paediatr 2021;94:81-104 DOI: $10.1159 / 000516407$
Wit/Joustra/Losekoot/van Duyvenvoorde/ de Bruin 
matomedin-C (IGF-I) level is a rather strong argument against this hypothesis. Genetic studies have not been reported for this patient.

The initial data on differences in bioactivity, binding properties, and metabolic clearance of the various $\mathrm{GH}$ isoproteins, as well as reports that different $\mathrm{GH}$ analogues and fragments may interact as weak agonists or antagonists of the GHR depending on the relative affinities of binding sites 1 and 2 to the GHR [153], were the reason for a Swedish group to test the hypothesis that short stature may be due to an abnormal distribution of GH isoproteins [154]. Serum non-22-kDa GH levels, expressed as a percentage of the total GH concentration, were determined by the $22-\mathrm{kDa} \mathrm{GH}$ exclusion assay. The median proportion of non-22-kDa GH isoforms was only slightly increased in children born SGA and girls with Turner syndrome but not in the group of children with ISS, compared with 23 normal-stature children (8.1\%). In the SGA group, the proportion of non-22-kDa GH isoforms was negatively correlated with height SDS. Although the proportion of non-22-kDa GH isoforms in children with ISS was not significantly different from that in normal-stature children, 2 children with ISS had markedly elevated proportions of non-22-kDa GH isoforms (>20\%), but in the same range as several girls with Turner syndrome [154]. Unfortunately, no specific clinical data on these children were presented, and further specification of the $\mathrm{GH}$ isoproteins was not performed. As far as we know, the potential role of abnormal GH isoproteins in growth failure has not been studied thereafter. We conclude that the current understanding that the various $\mathrm{GH}$ isoproteins have a similar biological activity and the absence of any convincing case report makes it unlikely that an abnormal $\mathrm{GH}$ isoprotein profile may cause unexplained short stature.

Disturbances of GH1 Expression by Variants in the Promoter Region

As with any genetic disorder, clinical features of a syndrome cannot only be caused by a pathogenic variant in the coding sequence of a gene but also in the $5^{\prime}$ or $3^{\prime}$ regions around the gene, including promoter regions or enhancers. In a few studies, allelic variants in the GH1 promoter were studied, as a potential cause of decreased GH secretion.

Wagner et al. [155] analysed the GH1 promoter region for structural alterations and allelic variations in $113 \mathrm{pa}-$ tients with isolated GHD type $1 \mathrm{~B}, 21$ unaffected family members, and 78 normal-stature controls. Of the 22 sequence variation sites, $14 \%$ were located around the re- gion of $-1,075 \mathrm{bp}, 77 \%$ between $-550 \mathrm{bp}$ and the translational start site ( $+1 \mathrm{bp})$, and $9 \%$ within the first intron. All the variations found in patients were also observed in non-affected family members as well as in normal unrelated controls. While these findings implied that there was not a single variation within the GH1 gene promoter, which causes isolated GHD, the authors could not exclude the possibility that combinations of variations might perturb expression.

The group from the Institute of Medical Genetics of the University of Wales College of Medicine did interesting work on the polymorphic variation in the proximal promoter and locus control region of GH1 [106, 156]. In a group of healthy male individuals, an association was noted between adult height and the mean in vitro expression value corresponding to an individual's $G H 1$ promoter haplotype combination, although it explained only $3.3 \%$ of the variance [156].

In the same year, Millar et al. [106] investigated GH1 variants, including $G H 1$ proximal promoter haplotypes, in 41 individuals with short stature, reduced height velocity, and bone delay, as well as in 11 individuals with idiopathic GHD and 154 controls. For the purpose of the present review, we concentrate on short individuals with a normal result in the GHST, a variant in the GH1 promoter region, and a $G H 1$ haplotype associated with a low expression level relative to the wt-haplotype. There were 3 individuals complying with these conditions. Cases 57 and 75 (with heights of -2.8 and -6.2 SDS and stimulated GH peaks of 27.3 and $6.8 \mu \mathrm{g} / \mathrm{L}$, respectively) carried a heterozygous variant in the proximal promoter $(-60 \mathrm{G}>\mathrm{A}$, recommended nomenclature according to [157]) associated with a haplotype with a low $G H 1$ expression (haplotype 19 according to Horan et al. [156]), inherited from their mothers. However, the mothers of both cases had a fully normal height SDS (0.3 and -0.6 SDS), which makes it unlikely that the variant is causative for the short stature of the child. Case 76 (with a height SDS of -2.2 and a GH peak of $18.3 \mu \mathrm{g} / \mathrm{L}$ ) carried a complex variant in the proximal promoter $(-216 \mathrm{~A}>\mathrm{G}$ and -40 -39delGGinsCT), associated with haplotype 17 (associated with a low GH1 expression). The variant was not found in the parents, who both were short ( -2.2 and -2.4 SDS), so also in this case a causative role of the variant in the patient's short stature is unlikely.

In a Dutch study on 62 individuals with isolated GHD, several GH1 promoter SNPs were associated with height and IGF-I levels among patients and controls, but no data were reported on short individuals with low serum IGF-I and a normal GHST [158]. In conclusion, the available 
evidence does not support the hypothesis that disturbances of $\mathrm{GH} 1$ expression by variants in de promoter region cause short stature in children with a low serum IGFI and normal GH peak in a GHST.

Disturbances in the Translation of GH1 mRNA

A disturbed GH1 RNA translation was suggested in a study on 3 short children with normal or high GH secretion, normal GHBP serum levels, low IGF-I serum levels, catch-up growth under rhGH treatment, and absence of any $G H 1$ variant or anti-hGH antibodies [159]. Serum samples were measured by polyclonal hGH-RIA, Nb2 rat lymphoma proliferation assay, and $\mathrm{GH}$ immunofunctional assay. In comparison to controls, the patients' serum $\mathrm{GH}$ levels were much lower when measured by $\mathrm{Nb} 2$ rat lymphoma cell proliferation bioassay and by the immunofunctional assay than by RIA. Retesting of 2 of the 3 patients including a 1 year break of therapy confirmed the rhGH dependence of growth in spite of normal endogenous GH secretion. The authors speculated that post-translational processing of $\mathrm{GH}$ might reduce the biological activity of the normal translation product.

\section{Conditions with Decreased GH Sensitivity}

In the following paragraphs, we shortly review the clinical features of the well-established causes of GHI characterized by low serum IGF-I (pathogenic variants of GHR, STAT5B, STAT3, IGF1, and IGFALS) and 2 syndromes where partial GHI appears likely (Noonan and $3 \mathrm{M})$. We also mention the unexplained occurrence of low serum IGF-I in rare patients carrying pathogenic heterozygous IGF1R defects, in contrast to the usual presentation with IGF-I concentrations in the upper half of the reference range or above [160].

Similarly to the continuous spectrum of GH secretion, there is also a continuous spectrum of severity of GH sensitivity. In addition, there is a large variability of the clinical presentation of individuals carrying pathogenic variants of GHR, STAT5B, STAT3, IGF1, and IGFALS. Therefore, any distinction between classical and non-classical forms, as previously proposed [27], is inevitably arbitrary. Still, for clinical purposes, such subclassification is useful, since the classical forms of these conditions, caused by a total functional loss of biological activity of the respective gene product, usually leads to such specific phenotype, that a candidate gene approach is warranted. Given the availability of recent reviews on these genetic disorders [27, 28, 161-164], we keep the descriptions of these conditions short.

\section{GHI due to GHR Defects}

The first reported disorder characterized by classical GHI was Laron syndrome (MIM \#262500), caused by a complete biallelic defect of the gene encoding the $\mathrm{GH}$ receptor $(G H R)$ [165]. Clinical features include extreme postnatal growth failure, midfacial hypoplasia, relatively normal head circumference, small external genitalia in males, sparse and thin hair, small hands and feet, delayed dentition and puberty, and hypoglycaemia. Biochemically, GH secretion is increased and serum concentrations of IGF-I, IGFBP-3, and ALS are severely subnormal and do not respond to an IGFGT. The serum concentration of GHBP is usually decreased but can be normal or even elevated depending on the position of the genetic variant $[27,161]$.

Non-classical GHI associated with $G H R$ variants includes the GHR pseudoexon variant $(6 \psi)$ and heterozygous GHR variants. For some heterozygous GHR variants, a dominant-negative effect has been confirmed, but for many others, the clinical relevance is questionable [27].

\section{GHI due to STAT5B Defects}

Homozygous variants of STAT5B, first reported in 2003 [166], cause a similar pattern as Laron syndrome with regard to growth, bone age, pubertal delay, facial characteristics, and serum IGF-I, IGFBP-3, and ALS (MIM \#245590). There are 2 additional, and characteristic, features: symptoms of immune dysfunction (e.g., severe eczema and chronic pulmonary disease) and elevated serum prolactin $[27,162]$.

A milder ("non-classical") clinical presentation was found in 3 probands with heterozygous dominant-negative STAT5B variants and several of their relatives [167]. Heights ranged from 2.9 to -5.3 SDS and eczema and elevated IgE were noted, without severe immune or pulmonary problems. Elevated serum prolactin was only found in one of the 3 probands $[27,162,167]$. A similar clinical presentation was shown by 2 unrelated patients with a heterozygous STAT5B variant in combination with a heterozygous IGFALS variant $[36,168]$. Other heterozygous $S T A T 5 B$ variants may also have some effect on growth and serum IGF-I, according to a study on heterozygous carriers of pathogenic STAT5B variants, without clinical features [169].

\section{GHI due to Activating Variants of STAT3}

Germline STAT3-activating (gain-of-function) variants result in early-onset multiorgan autoimmunity, lymphoproliferation, recurrent infections, and short stature
Horm Res Paediatr 2021;94:81-104 DOI: $10.1159 / 000516407$
Wit/Joustra/Losekoot/van Duyvenvoorde/ de Bruin 
(MIM \#615952). There are indications that such STAT3 variants may negatively regulate $\mathrm{GH}$-induced STAT5B activation through the induction of SOCS3 protein, the formation of non-functional STAT3/STAT5 heterodimers, or through the competition for binding to target gene loci, activating different transcriptional programmes (reviewed in [163]). Milder forms with isolated growth failure have not been reported.

\section{GHI due to IGF1 Variants}

IGF1 variants can be categorized into biallelic loss-offunction variants, biallelic variants with decreased function, and heterozygous variants [28]. The classical presentation of children with a homozygous loss-of-function variant consists of extreme pre- and postnatal growth failure, poor feeding, severe microcephaly, retrognathia, sensorineural deafness, and severe global developmental delay (MIM \#608747, reviewed in [28]). The first case with a deletion was reported in 1996 [170], followed by 2 cases with a missense variant $[171,172]$. Cases carrying a biallelic $I G F 1$ variant with decreased function have a milder phenotype, without hearing loss and developmental delay [173]. Serum IGF-I varies from undetectable to elevated, and IGFBP-3 and ALS are generally normal [28].

Heterozygosity for a pathogenic IGF1 variant or deletion can cause short stature [174-176] with a wide height SDS range. In 1 family, no dominant-negative effect of the truncated protein was shown [177]. A small effect of heterozygosity for a pathogenic IGF1 variant on growth and adult stature was also shown in relatives of patients with a homozygous IGF1 variant $[171,172,178]$.

\section{GHI due to IGFALS Variants}

The characteristic clinical presentation of individuals carrying 2 pathogenic variants of IGFALS, first reported in 2004 [179], is mild-to-moderate short stature, delayed puberty, low serum IGF-I and ALS SDS, and even lower IGFBP-3 SDS (MIM \#615961). A low birth weight and/or length, reduced head circumference, and insulin resistance are commonly observed (for review, see [164]). Heterozygous carriers of an IGFALS variant frequently present with mild growth failure and subnormal levels of ALS, IGFBP-3, and IGF-I $[164,180]$ and were reported in approximately $10 \%$ of children initially considered "idiopathic short stature" $[164,181]$.

\section{Unexplained Low Serum IGF-I in 2 Cases with}

Heterozygous IGF1R Variants

As mentioned previously, the great majority of children carrying a heterozygous pathogenic IGF1R variant
(MIM \#270450) have a serum IGF-I in the upper half of the reference range or above [160]. However, at least 2 children presented with a decreased IGF-I concentration $[182,183]$, which has remained unexplained.

\section{Syndromes with Dysmorphic Features Associated with}

Diminished GH Sensitivity

Partial GHI has been suggested for children with Noonan syndrome (MIM \#163950) based on the observation of low IGF-I values, preserved GH secretion, and suboptimal growth response to rhGH therapy (reviewed in [184]). The precise mechanism is still unclear and may be associated with an increase in tyrosine phosphatase activity, since SHP-2 binds to and dephosphorylates signalling molecules such as STAT5b [27]. Alternatively, activation of the RAS/MAPK pathway may play a role [184].

Three-M (3M) syndrome (MIM \#273750) is associated with normal or high peak $\mathrm{GH}$ levels and normal or low IGF-I levels, and the growth response to rhGH is usually low. In vitro studies have provided evidence for a combined insensitivity to GH and IGF-I [185].

\section{Abnormal Interaction of IGF-I with Its Chaperones}

Even if there is no abnormality of the coding region of the IGF1 gene nor in its expression and translation, the secretion of IGF-I may be decreased by other causes. One potential cause could be an insufficient functionality of the chaperone protein that is needed for a normal secretion of IGF-I and -II, that is, the chaperone glucose-regulated protein 94 (GRP94) [186]. Indeed, a hypomorphic variant (p.(Pro300Leu) variant NM_003299.2: c.962C >T p.(Pro321Leu) according to the HGVS nomenclature) was found in a child with primary IGF deficiency but was later considered a non-common SNP with frequencies of $1-4 \%$ in various populations [187]. Heterozygous carriers had a 9\% lower circulating IGF-I concentration than non-carriers. When tested in the grp94(-/-) cell-based complementation assay, Pro300Leu supported only 58\% of IGF secretion relative to wt-GRP94. Furthermore, recombinant Pro300Leu showed impaired nucleotidebinding activity. The authors concluded that variants in GRP94 can affect its IGF-chaperone activity, which may represent a novel causal genetic mechanism that limits IGF biosynthesis [187], although this needs further confirmation.

\section{Therapeutic Options for Children with GHI}

The classical forms of GHI generally do not respond to rhGH treatment. For children with Laron syndrome, rhIGF is a registered treatment, leading to a modest in- 
crease in height velocity and adult height [188]. There are few data on the effect of rhIGF in cases with homozygous or heterozygous STAT5B or IGF1 defects. Preliminary observations suggest that rhGH may have a positive effect in cases with heterozygous IGF1 variants [174].

While in children with biallelic IGFALS variants, rhGH and rhIGF appear ineffective, preliminary reports have suggested that rhGH could be effective to accelerate growth velocity in children who are heterozygous carriers of IGFALS variants $[164,189]$. rhGH is registered for the treatment of Noonan syndrome, based on the moderate effect on height velocity and adult height [190]. The growth response to rhGH treatment in children with $3 \mathrm{M}$ syndrome is variable and modest [185]. Interestingly, GH treatment appears effective in increasing growth in girls with anorexia nervosa, despite the GHI associated with this condition [191].

\section{Hypothetical Causes of Short Stature Associated with a Low Serum IGF-I and Normal Stimulated GH Peak}

The current differential diagnosis is of course completely dependent on the presently available genetic toolkit in the clinic. However, in the meantime, new techniques have developed in basic science, which have not found their way to the clinic yet. One can expect that further technological advances will take place, which will help to get more insight into the complex signalling pathway of the GH-IGF-I axis. In the following paragraph, we speculate about the sort of clinical insights that may be generated using an intensified clinical use of presently available technology.

\section{Intensified Use of Exome and Genome Sequencing}

The past decades have shown an accelerating speed of discoveries of novel genetic causes of multiple congenital disorders, including disorders of the GH-IGF-I axis. There is little reason to think that this has reached the end.

Pituitary GH secretion is mainly controlled by GHRH and somatostatin [192], so one would expect that defects of the genes encoding these proteins or their receptors would cause abnormal GH secretion. Besides defects of the gene encoding the GHRH receptor, causing GHD type $1 \mathrm{~B}$, no genetic aberrations have been found in the genes encoding GHRH, somatostatin, and somatostatin receptors.

In theory, an activating variant in a somatostatin receptor expressed in the pituitary might cause a decrease in GH secretion, serum IGF-I, and height, and the result of a GHST acting through GHRH activation could be normal. Four out of the total of 5 somatostatin receptors are expressed in the pituitary, but predominantly the receptors encoded by SSTR 2 and SSTR5. Interestingly, in a study on patients with acromegaly and controls, 2 polymorphisms in SSTR5 were associated with serum IGF-I and IGFBP-3 [193]. Another SSTR5 variant was associated with $11 \%$ lower levels of circulating IGF-I and IGFBP-3 [194]. We speculate that genetic variants will be discovered in somatostatin receptors or other components of the complex GH regulatory system, which may cause short stature associated with low IGF-I and a normal GHST result.

\section{Potential Yield of Studies on Cellular Pituitary}

Crosstalk ("Paracrinicity")

So far, the publications on cellular pituitary crosstalk have only reached the eyes of few clinical endocrinologists. However, these studies have generated very interesting information that theoretically may be associated with clinical phenotypes. To cite one of the key investigators in this field, Dr. C. Denef from Louvain (Belgium): "in the anterior pituitary, paracrine communication and autocrine loops that operate during foetal and postnatal development in mammals and lower vertebrates have been shown in all hormonal cell types and in folliculostellate cells. More than 100 compounds have been identified that have, or may have, paracrine or autocrine actions" [195].

We believe that the studies on the induction of functional hypothalamus and pituitary tissues from pluripotent stem cells, which may result in an "artificial pituitary" [196], may generate novel insights in the complex cellular intra-pituitary interactions. This may also lead to novel defects of GH secretion that have still remained in hiding.

An example of a condition that may be associated with abnormal cellular pituitary crosstalk is the IGSF1 deficiency syndrome (MIM \#300888, caused by a hemizygous defect of IGSF1 [197]), in view of decreased Igsf1 expression in the somatotroph, lactotroph, and thyrotroph cells in the rat [198] and variable deficiency of the respective pituitary hormones in humans. Partial and transient GHD is encountered in approximately $10 \%$ of males with IGSF1 deficiency syndrome, while GH secretion tends to increase above the normal range in adults [199].
96

Horm Res Paediatr 2021;94:81-104 DOI: $10.1159 / 000516407$
Wit/Joustra/Losekoot/van Duyvenvoorde/ de Bruin 
Potential Yield of Tools to Estimate DNA Methylation

Status and Histone Modification

Imprinting Disorders and Other Methylation

Disturbances

The best known imprinting disorders, for example, uniparental disomy and other methylation disturbances, associated with short stature include Silver-Russell syndrome, Temple syndrome, IMAGe syndrome, and Prader-Willi syndrome. Three out of the 5 forms of SilverRussell syndrome (MIM \#180860, \#618905, and \#616489) are known to be caused by an imprinting disorder [200]. The $40 \%$ of patients with the clinical features of SilverRussell syndrome in whom no (epi-)genetic cause can be found with current technology suggest that other forms may be detected in the future, although these patients usually show normal or slightly elevated IGF-I. The GHIGF-I axis in Temple syndrome (MIM \#616222) and IMAGe syndrome (MIM \#614732) has not been investigated in depth. So far, there is little indication that this axis is affected, except for 1 case with IMAGe syndrome with a low GH peak [201]. In short children born SGA, several DNA methylation changes at multiple loci were observed $[202,203]$, but the potential association with the GHIGF-I axis remains to be established.

\section{Histone Modification}

The expression of genes is not only regulated by methylation status but also by histone modification. There are a number of genes encoding enzymes that catalyse posttranslational histone modifications, such as methyltransferases, demethylases, acyltransferases, chromodomain helicases, and arginine-methyltransferases. An indication that abnormal modification may play a role in growth regulation is offered by the observation that pathogenic variants of $K D M 3 B$ cause intellectual disability, short stature, and facial dysmorphism. KDM3B encodes a histone demethylase and is involved in H3K9 demethylation, a crucial part of chromatin modification required for transcriptional regulation [204]. A better insight in histone physiology may lead to novel tests for aberrations of histone functionality and possibly novel syndromes associated with low IGF-I and normal GH secretion.

\section{Potential Yield of RNA Sequencing}

RNA sequencing is available in the laboratory but has rarely been used in the clinic. Still, RNA sequencing has helped in re-evaluating and further classifying the genetic variants found by exome sequencing, such as confirmation of putative splicing mutations [205]. It is also used to determine whether 2 variants in the same gene are localized on the same or different chromosome and to detect monogenic defects undetected by exome sequencing (e.g., a deep intronic variant leading to a pseudoexon) [206, 207].

RNA sequencing can also be targeted to analyse long non-coding RNAs (lncRNA). lncRNAs are transcripts of $>200$ nucleotides in length not containing an extended open reading frame; $28,000 \operatorname{lncRNAs}$ are annotated in the human genome. Defects have been associated with a number of diseases, including Silver-Russell syndrome (H19), Temple syndrome, cartilage-hair hypoplasia, and Turner syndrome (XIST) [208].

Specific PCR tests have been developed for microRNAs (miRNA expression profiles). miRNAs are epigenetic regulators of gene expression that act at the post-transcriptional level, influencing regulatory gene networks [209]. Several miRNAs regulate the growth plate and GHIGF axis, contributing to longitudinal growth. For example, miR-709 inhibits GHRP6-induced GH synthesis by targeting PRKCA in the pituitary $[209,210]$. There are indications that miRNAs are also involved in catch-up growth in children born SGA [211].

\section{General Conclusions}

The differential diagnosis of a non-syndromic short child with low circulating IGF-I and a normal GH peak in a stimulation test is extensive. Numerical data are not available, but our impression is that the major causes are discordance between stimulated and spontaneous GH secretion and partial GHI (including Noonan syndrome, which can present with few dysmorphic features). Of the genetic conditions associated with normal GH sensitivity, bioinactive $\mathrm{GH}$ (Kowarski syndrome), is well documented, while there is still doubt about the role of GHSR variants.

We believe that genetic assessment of such patients is indicated, given that for cases with classical GHI, such as Laron syndrome and biallelic STAT5B variants, GH treatment is not warranted. Instead, such patients are candidates for rhIGF treatment. However, various other genetic disorders are expected to respond well to rhGH treatment, such as heterozygous carriers of IGF1 or IGFALS variants.

For an effective diagnosis of such patients as well as other patients suspected for one of the many genetic disorders associated with short stature, the establishment of a multidisciplinary team on growth genetics has proven to be very beneficial, as well as a joint clinic of a paediatric endocrinologist and clinical geneticist. A challenge for the future is how to deal with previous patients suspected 
for a genetic aetiology with initially negative genetic findings. We believe that a guideline is needed on the selection of such patients who may be called back to the clinic when new genetic tools become available in future years. The potential advantage of such an approach is illustrated by the observation that re-analysis of exome data of children with developmental disorders increased the diagnostic yield from 27 to $40 \%$ [212].

\section{Acknowledgements}

This minireview was inspired by, and is a tribute to, Dr. MarieJosé E. Walenkamp, who played a crucial role in developing the IGFGT and in unravelling the genetic aetiologies of short children. Marie-José Walenkamp was planned to co-author this minireview, but unfortunately, this was made impossible because of a sudden devastating disease. She sadly passed away in March 2021, much too young. We are grateful to Drs. Kerstin Albertsson-Wikland and Berit Kristrom for helpful advice on the section on spontaneous GH secretion and for kind consent to present Figure 1 .

\section{Conflict of Interest Statement}

The authors have no conflicts of interest to disclose.

\section{Funding Sources}

The authors did not receive any funding.

\section{Author Contributions}

J.M.W. initiated this review, reviewed the literature, and took the lead in writing the text. S.D.J., M.L., H.A.D., and C.B. revised previous versions of the manuscript. M.L. and H.A.D. revised the tables and the text on genetic issues. All authors read and approved the submitted manuscript.

\section{References}

1 Shen Y, Zhang J, Zhao Y, Yan Y, Liu Y, Cai J. Diagnostic value of serum IGF-1 and IGFBP-3 in growth hormone deficiency: a systematic review with meta-analysis. Eur J Pediatr. 2015;174(4):419-27.

2 Blum WF, Alherbish A, Alsagheir A, El Awwa A, Kaplan W, Koledova E, et al. The growth hormone-insulin-like growth factor-I axis in the diagnosis and treatment of growth disorders. Endocr Connect. 2018;7(6):R212-22.

3 Wit JM, Kamp GA, Oostdijk W, on behalf of the Dutch Working Group on Triage and Diagnosis of Growth Disorders in Children. Towards a rational and efficient diagnostic approach in children referred for growth failure to the general pediatrician. Horm Res Paediatr. 2019;91(4):223-40.

4 Wit JM, Bidlingmaier M, de Bruin C, Oostdijk W. A proposal for the interpretation of serum IGF-I concentration as part of laboratory screening in children with growth failure. J Clin Res Pediatr Endocrinol. 2020;12(2): 130-9.

5 Ibba A, Corrias F, Guzzetti C, Casula L, Salerno $\mathrm{M}$, di Iorgi N, et al. IGF1 for the diagnosis of growth hormone deficiency in children and adolescents: a reappraisal. Endocr Connect. 2020;9(11):1095-102.

6 Grimberg A, DiVall SA, Polychronakos C, Allen DB, Cohen LE, Quintos JB, et al. Guidelines for growth hormone and insulin-like growth factor-I treatment in children and adolescents: growth hormone deficiency, idiopathic short stature, and primary insulin-like growth factor-I deficiency. Horm Res Paediatr. 2016;86(6):361-97.
7 Collett-Solberg PF, Ambler G, Backeljauw PF, Bidlingmaier M, Biller BMK, Boguszewski MCS, et al. Diagnosis, genetics, and therapy of short stature in children: a growth hormone research society international perspective. Horm Res Paediatr. 2019;92(1):1-14.

8 Juul A, Dalgaard P, Blum WF, Bang P, Hall K, Michaelsen KF, et al. Serum levels of insulinlike growth factor (IGF)-binding protein- 3 (IGFBP-3) in healthy infants, children, and adolescents: The relation to IGF-I, IGF-II, IGFBP-1, IGFBP- 2, age, sex, body mass index, and pubertal maturation. J Clin Endocrinol Metab. 1995;80(8):2534-42.

9 Lofqvist C, Andersson E, Gelander L, Rosberg S, Blum WF, Albertsson WK. Reference values for IGF-I throughout childhood and adolescence: a model that accounts simultaneously for the effect of gender, age, and puberty. J Clin Endocrinol Metab. 2001;86(12): $5870-6$.

10 Rosenfeld RG, Albertsson-Wikland K, Cassorla F, Frasier SD, Hasegawa Y, Hintz RL, et al. Diagnostic controversy: the diagnosis of childhood growth hormone deficiency revisited. J Clin Endocrinol Metab. 1995;80(5): 1532-40.

11 Ghigo E, Bellone J, Aimaretti G, Bellone S, Loche S, Cappa M, et al. Reliability of provocative tests to assess growth hormone secretory status. Study in 472 normally growing children. J Clin Endocrinol Metab. 1996;81(9): 3323-7.

12 Carel JC, Tresca JP, Letrait M, Chaussain JL, Lebouc Y, Job JC, et al. Growth hormone testing for the diagnosis of growth hormone de- ficiency in childhood: a population registerbased study. J Clin Endocrinol Metab. 1997; 82(7):2117-21.

13 Lin T, Tucci JR. Provocative tests of growthhormone release. A comparison of results with seven stimuli. Ann Intern Med. 1974; 80(4):464-9.

14 Tassoni P, Cacciari E, Cau M, Colli C, Tosi M, Zucchini S, et al. Variability of growth hormone response to pharmacological and sleep tests performed twice in short children. J Clin Endocrinol Metab. 1990;71(1):230-4.

15 Zadik Z, Chalew SA, Gilula Z, Kowarski AA Reproducibility of growth hormone testing procedures: a comparison between 24-hour integrated concentration and pharmacological stimulation. J Clin Endocrinol Metab. 1990;71:1127-30.

16 Yackobovitch-Gavan M, Lazar L, Diamant R Phillip M, Oron T. Diagnosis of growth hormone deficiency in children: the efficacy of glucagon versus clonidine stimulation test. Horm Res Paediatr. 2020;93(7-8):470-6.

17 Zadik Z, Chalew SA, Kowarski A. Assessment of growth hormone secretion in normal stature children using 24-hour integrated concentration of GH and pharmacological stimulation. J Clin Endocrinol Metab. 1990;71(4): 932-6.

18 Marin G, Domene HM, Barnes KM, Blackwell BJ, Cassorla FG, Cutler GB Jr. The effects of estrogen priming and puberty on the growth hormone response to standardized treadmill exercise and arginine-insulin in normal girls and boys. J Clin Endocrinol Metab. 1994; 79(2):537-41. 
19 Lodefalk M, Nilsson O. To prime or not to prime-Is that still a question? A comment on the US guidelines on growth hormone and insulin-like growth factor-I treatment in children and adolescents. Horm Res Paediatr. 2017;88(2):179-80.

20 Albertsson-Wikland K, Rosberg S. Methods of evaluating spontaneous growth hormone secretion. In: Ranke MB, Mullis P-E, editors. Diagnostics of endocrine function in children and adolescents. Basel: Karger; 2011. p. 13856.

21 Yang A, Cho SY, Kwak MJ, Kim SJ, Park SW, Jin DK, et al. Impact of BMI on peak growth hormone responses to provocative tests and therapeutic outcome in children with growth hormone deficiency. Sci Rep. 2019;9(1): 16181.

22 Jansson C, Boguszewski C, Rosberg S, Carlsson L, Albertsson-Wikland K. Growth hormone $(\mathrm{GH})$ assays: influence of standard preparations, GH isoforms, assay characteristics, and GH-binding protein. Clin Chem. 1997;43(6 Pt 1):950-6.

23 Gelander L, Albertsson-Wikland K. Growth hormone $(\mathrm{GH})$ release after administration of $\mathrm{GH}$-releasing hormone in relation to endogenous 24-h GH secretion in short children. J Endocrinol. 1989;122(1):61-8.

24 Lennartsson O, Nilsson O, Lodefalk M. Discordance between stimulated and spontaneous growth hormone levels in short children is dependent on cut-off level and partly explained by refractoriness. Front Endocrinol. 2020;11:584906.

25 Juul A, Bernasconi S, Clayton PE, Kiess W, DeMuinck-Keizer SS. European audit of current practice in diagnosis and treatment of childhood growth hormone deficiency. Horm Res. 2002;58(5):233-41.

26 Binder G, Reinehr T, Ibanez L, Thiele S, Linglart A, Woelfle J, et al. GHD diagnostics in Europe and the US: an audit of national guidelines and practice. Horm Res Paediatr. 2019;92(3):150-6.

27 Storr HL, Chatterjee S, Metherell LA, Foley C, Rosenfeld RG, Backeljauw PF, et al. Nonclassical GH insensitivity: characterization of mild abnormalities of GH action. Endocr Rev. 2019;40(2):476-505.

28 Forbes BE, Blyth AJ, Wit JM. Disorders of IGFs and IGF-1R signaling pathways. Mol Cell Endocrinol. 2020;518:111035.

29 Rudman D, Kutner MH, Blackston RD, Cushman RA, Bain RP, Patterson JH. Children with normal-variant short stature: treatment with human growth hormone for six months. N Engl J Med. 1981;305(3):123-31.

30 Wit JM, Van den Brande JL. Plasma somatomedin activity and urinary hydroxyproline excretion during administration of human growth hormone in children with short stature. Long-term effects and relation with short-term changes. Horm Res. 1984;19(4): 216-23.
31 Albertsson-Wikland K, Hall K. Growth hormone treatment in short children: relationship between growth and serum insuline-like growth factor I and II levels. J Clin Endocrinol Metab. 1987;65:671-8.

32 Blum WF, Cotterill AM, Postel Vinay MC, Ranke MB, Savage MO, Wilton P. Improvement of diagnostic criteria in growth hormone insensitivity syndrome: solutions and pitfalls. Pharmacia Study Group on Insulinlike Growth Factor I Treatment in Growth Hormone Insensitivity Syndromes. Acta Paediatr Suppl. 1994;399:117-24.

33 Blair JC, Camacho-Hubner C, Miraki MF, Rosberg S, Burren C, Lim S, et al. Standard and low-dose IGF-I generation tests and spontaneous growth hormone secretion in children with idiopathic short stature. Clin Endocrinol. 2004;60(2):163-2.

34 Buckway CK, Guevara-Aguirre J, Pratt KL, Burren CP, Rosenfeld RG. The IGF-I generation test revisited: a marker of GH sensitivity. J Clin Endocrinol Metab. 2001;86(11):517683.

35 Coutant R, Dorr HG, Gleeson H, Argente J. Diagnosis of endocrine disease: limitations of the IGF1 generation test in children with short stature. Eur J Endocrinol. 2012;166(3): 351-7.

36 Wit JM, van Duyvenvoorde HA, Scheltinga SA, de Bruin S, Hafkenscheid L, Kant SG, et al. Genetic analysis of short children with apparent growth hormone insensitivity. Horm Res Paediatr. 2012;77(5):320-33.

37 Kowarski A, Thompson RG, Migeon CJ, Blizzard RM. Determination of integrated plasma concentrations and true secretion rates of human growth hormone. J Clin Endocrinol Metab. 1971;32(3):356-60.

38 Finkelstein JW, Roffwarg HP, Boyard RM, Kream J, Hellman L. Age-related change in the twenty-four-hour spontaneous secretion of growth hormone. J Clin Endocrinol Metab. 1972:35:665-70.

39 Parker LG, Kripke DF. Rhytmicities in human growth hormone concentrations in plasma. In: Krieger DT, editor. Endocrine rhythms. New York: Raven Press; 1979.

40 Plotnick LP, Lee PA, Migeon CJ, Kowarski AA. Comparison of physiological and pharmacological tests of growth hormone function in children with short stature. J Clin Endocrinol Metab. 1979;48(5):811-5.

41 Chrousos GP, Poplack D, Brown T, O'Neill D, Schwade J, Bercu BB. Effects of cranial radiation on hypothalamic-adenohypophyseal function: abnormal growth hormone secretory dynamics. J Clin Endocrinol Metab. 1982;54(6):1135-9.

42 Blatt J, Bercu BB, Gillin JC, Mendelson WB, Poplack DG. Reduced pulsatile growth hormone secretion in children after therapy for acute lymphoblastic leukemia. J Pediatr. 1984; 104(2):182-6.

43 Lannering B, Albertsson-Wikland K. Growth hormone release in children after cranial irradiation. Horm Res. 1987;27(1):13-22.
44 Albertsson-Wikland K, Lannering B, Marky I, Mellander L, Wannholt U. A longitudinal study on growth and spontaneous growth hormone $(\mathrm{GH})$ secretion in children with irradiated brain tumors. Acta Paediatr Scand. 1987;76(6):966-73.

45 Blatt J, Lee P, Suttner J, Finegold D. Pulsatile growth hormone secretion in children with acute lymphoblastic leukemia after 1800 cGy cranial radiation. Int J Radiat Oncol Biol Phys. 1988;15(4):1001-6.

46 Moell C, Garwicz S, Westgren U, Wiebe T, Albertsson-Wikland K. Suppressed spontaneous secretion of growth hormone in girls after treatment for acute lymphoblastic leukaemia. Arch Dis Child. 1989;64(2):252-8.

47 Lannering B, Rosberg S, Marky I, Moell C, Albertsson-Wikland K. Reduced growth hormone secretion with maintained periodicity following cranial irradiation in children with acute lymphoblastic leukaemia. Clin Endocrinol. 1995;42(2):153-9.

48 Schmiegelow M, Lassen S, Poulsen HS, FeldtRasmussen U, Schmiegelow K, Hertz H, et al. Growth hormone response to a growth hormone-releasing hormone stimulation test in a population-based study following cranial irradiation of childhood brain tumors. Horm Res. 2000;54(2):53-9.

49 Albertsson-Wikland K, Kristrom B, Rosberg S, Svensson B, Nierop AF. Validated multivariate models predicting the growth response to GH treatment in individual short children with a broad range in GH secretion capacities. Pediatr Res. 2000;48(4):475-84.

50 Kristrom B, Aronson AS, Dahlgren J, Gustafsson J, Halldin M, Ivarsson SA, et al. Growth hormone $(\mathrm{GH})$ dosing during catch-up growth guided by individual responsiveness decreases growth response variability in prepubertal children with GH deficiency or idiopathic short stature. J Clin Endocrinol Metab. 2009;94(2):483-90.

51 Zadik Z, Chalew SA, McCarter RJ Jr, Meistas $\mathrm{M}$, Kowarski AA. The influence of age on the 24-hour integrated concentration of growth hormone in normal individuals. J Clin Endocrinol Metab. 1985;60(3):513-6.

52 Albertsson-Wikland K, Rosberg S. Analyses of 24-hour growth hormone profiles in children: relation to growth. J Clin Endocrinol Metab. 1988;67(3):493-500.

53 Rose SR, Municchi G, Barnes KM, Kamp GA, Uriarte MM, Ross JL, et al. Spontaneous growth hormone secretion increases during puberty in normal girls and boys. J Clin Endocrinol Metab. 1991;73(2):428-35.

54 Albertsson-Wikland K, Rosberg S, Karlberg J, Groth T. Analysis of 24-hour growth hormone profiles in healthy boys and girls of normal stature: relation to puberty. J Clin Endocrinol Metab. 1994;78(5):1195-201. 
55 Martha PM Jr., Rogol AD, Veldhuis JD, Blizzard RM. A longitudinal assessment of hormonal and physical alterations during normal puberty in boys. III. The neuroendocrine growth hormone axis during late prepuberty. I Clin Endocrinol Metab. 1996;81(11):406874.

56 Albertsson-Wikland K, Rosberg S, Libre E, Lundberg LO, Groth T. Growth hormone secretory rates in children as estimated by deconvolution analysis of 24-h plasma concentration profiles. Am J Physiol. 1989;257(6 Pt 1):E809-14

57 Hindmarsh P, Smith PJ, Brook CGD, Matthews DR. The relationship between height velocity and growth hormone secretion in short prepubertal children. Clin Endocrinol (Oxf). 1987;27:581-91.

58 Spiliotis BE, August GP, Hung W, Sonis W, Mendelson W, Bercu BB. Growth hormone neurosecretory dysfunction. A treatable cause of short stature. JAMA. 1984;251(17):222330.

59 Bercu BB, Shulman D, Root AW, Spiliotis BE. Growth hormone $(\mathrm{GH})$ provocative testing frequently does not reflect endogenous GH secretion [published erratum appears in J Clin Endocrinol Metab 1987 Feb;64(2):382]. J Clin Endocrinol Metab. 1986;63(3):709-16.

60 Rose SR, Ross JL, Uriarte M, Barnes KM, Cassorla FG, Cutler GB Jr. The advantage of measuring stimulated as compared with spontaneous growth hormone levels in the diagnosis of growth hormone deficiency. N Engl J Med. 1988;319(4):201-7.

61 Albertsson-Wikland K, Rosberg S. Reproducibility of 24-h growth hormone profiles in children. Acta Endocrinol. 1992;126:109-12.

62 Saini S, Hindmarsh PC, Matthews DR, Pringle PJ, Jones J, Preece MA, et al. Reproducibility of 24-hour serum growth hormone profiles in man. Clin Endocrinol (Oxf). 1991; 34(6):455-62.

63 Cacciari E, Tassoni P, Cicognani A, Pirazzoli P, Salardi S, Balsamo A, et al. Value and limits of pharmacological and physiological tests to diagnose growth hormone (GH) deficiency and predict therapy response: first and second retesting during replacement therapy of patients defined as GH deficient. J Clin Endocrinol Metab. 1994;79:1663-9.

64 Ropelato MG, Martinez A, Heinrich JJ, Bergada C. Reproducibility and comparison of growth hormone secretion tests. J Pediatr Endocrinol Metab. 1996;9(1):41-50.

65 Groth T, Rosberg S, Albertsson-Wikland K. Estimation of growth hormone secretory patterns in children with use of a numerical deconvolution technique: experimental design with use of computer simulation. Horm Res. 1994;42(6):245-52.

66 Shulman DI, Bercu BB. Evaluation of growth hormone secretion: provocative testing vs endogenous 24-hour growth hormone profile. Acta Paediatr Scand Suppl. 1987;337:61-71.
67 Shulman DI, Martinez CR, Bercu BB, Root AW. Hypothalamic-pituitary dysfunction in primary empty sella syndrome in childhood. J Pediatr. 1986;108(4):540-4.

68 Zadik Z, Chalew SA, Raiti S, Kowarski AA. Do short children secrete insufficient growth hormone? Pediatrics. 1985;76(3):355-60.

69 Zadik Z, Kowarski A. Incidence of neurosecretory dysfunction among children aged 6-14 years in Rehovot, Israel. Acta Paediatr Scand Suppl. 1989;349:77-80; discussion 81-

70 Zadik Z, Chalew SA, Kowarski A. The definition of a spontaneous growth hormone $(\mathrm{GH})$ peak-studies in normally growing and GHdeficient children. J Clin Endocrinol Metab. 1992;74:801-5.

71 Zadik Z, Limoni Y, Lieberman E. Chronic growth hormone administration does not suppress endogenous growth hormone secretion in patients with neurosecretory growth hormone dysfunction. Horm Res. 1991;35: 95-8.

72 Lundberg E, Andersson B, Kristrom B, Rosberg S, Albertsson-Wikland K. Broad variability in pharmacokinetics of GH following rhGH injections in children. Growth Horm IGF Res. 2018;40:61-8.

73 Zadik Z, Chalew S, Zung A, Landau H, Leiberman E, Koren R, et al. Effect of long-term growth hormone therapy on bone age and pubertal maturation in boys with and without classic growth hormone deficiency. J Pediatr. 1994;125(2):189-95.

74 Zadik Z, Mira U, Landau H. Final height after growth hormone therapy in peripubertal boys with a subnormal integrated concentration of growth hormone. Horm Res. 1992;37(4-5): 150-5.

75 Zadik Z, Zung A, Sarel R, Cooper M. Evolving growth hormone deficiency in children with a subnormal secretion of growth hormone. J Pediatr. 1997;130(3):481-4.

76 Schwartz ID, Hu CS, Shulman DI, Root AW Bercu BB. Linear growth response to exogenous growth hormone in children with short stature. Am J Dis Child. 1990;144(10):1092-7.

77 Root AW, Duckett GE, Geiszler JE, Hu CS, Bercu BB. Evaluation of the clinical utility of the ultrasensitive immunofluometric assay for growth hormone $(\mathrm{GH})$ and of the cortisol secretory pattern in prediction of the linear growth response to treatment with $\mathrm{GH}$. J Pediatr Endocrinol Metab. 1997;10(1):3-10.

78 Diamond FB, Jorgensen EV, Root AW, Shulman DI, Sy JP, Blethen SL, et al. The role of serial sampling in the diagnosis of growth hormone deficiency. Pediatrics. 1998;102(2 Pt 3):521-4.

79 Burman P, Ritzen EM, Lindgren AC. Endocrine dysfunction in Prader-Willi syndrome: a review with special reference to GH. Endocr Rev. 2001;22(6):787-99.

80 Grugni G, Marzullo P. Diagnosis and treatment of GH deficiency in Prader-Willi syndrome. Best Pract Res Clin Endocrinol Metab. 2016;30(6):785-94.
81 Grugni G, Crino A, Pagani S, Meazza C, Buzi F, De Toni T, et al. Growth hormone secretory pattern in non-obese children and adolescents with Prader-Willi syndrome. J Pediatr Endocrinol Metab. 2011;24(7-8):477-81.

82 Lindgren AC, Hagenas L, Muller J, Blichfeldt S, Rosenborg M, Brismar T, et al. Growth hormone treatment of children with Prader-Willi syndrome affects linear growth and body composition favourably. Acta Paediatr. 1998; $87(1): 28-31$.

83 Donze SH, Damen L, van Alfen-van der Velden J, Bocca G, Finken MJJ, HoorwegNijman GJG, et al. Prevalence of growth hormone $(\mathrm{GH})$ deficiency in previously GHtreated young adults with Prader-Willi syndrome. Clin Endocrinol (Oxf). 2019;91(1): $118-23$.

84 Rose SR, Municchi G, Barnes KM, Cutler GB Jr. Overnight growth hormone concentrations are usually normal in pubertal children with idiopathic short stature: a Clinical Research Center study. J Clin Endocrinol Metab. 1996;81(3):1063-8.

85 Dahlgren J, Kristrom B, Niklasson A, Nierop AF, Rosberg S, Albertsson-Wikland K. Models predicting the growth response to growth hormone treatment in short children independent of GH status, birth size and gestational age. BMC Med Inform Decis Mak. 2007;7:40.

86 Kristrom B, Lofqvist C, Rosberg S, Albertsson WK. Effect of spontaneous GH secretion and the GH sampling period on the accuracy of models for predicting growth responses to GH treatment. J Clin Endocrinol Metab. 2001;86(10):4963-4.

87 Zadik Z, Chalew SA, Kowarski A. The diagnostic value of integrated growth hormone secretion studies shorter than 24 hours in normal- and short-growing children. Horm Res. 1992;38(5-6):250-5.

88 Boguszewski M, Rosberg S, Albertsson-Wikland K. Spontaneous 24-hour growth hormone profiles in prepubertal small for gestational age children. J Clin Endocrinol Metab. 1995;80(9):2599-606.

89 Ranke MB, Schweizer R, Binder G. Basal characteristics and first year responses to human growth hormone $(\mathrm{GH})$ vary according to diagnostic criteria in children with non-acquired GH deficiency (naGHD): observations from a single center over a period of five decades. J Pediatr Endocrinol Metab. 2018; 31(11):1257-66.

90 Duchen K, Lindberg A, Kiplok K, Kristrom B. Using a spontaneous profile rather than stimulation test makes the KIGS idiopathic growth hormone deficiency model more accessible for clinicians. Acta Paediatr. 2017;106(9): 1481-6.

91 Kristrom B, Lundberg E, Jonsson B, Albertsson-Wikland K, Study Group. IGF-1 and growth response to adult height in a randomized GH treatment trial in short non-GH-deficient children. J Clin Endocrinol Metab. 2014;99(8):2917-24. 
92 Lundberg E, Kristrom B, Jonsson B, Albertsson-Wikland K; Study Group. Growth hormone (GH) dose-dependent IGF-I response relates to pubertal height gain. BMC Endocr Disord. 2015;15:84.

93 Mullis PE. Genetics of GHRH, GHRH-receptor, GH and GH-receptor: its impact on pharmacogenetics. Best Pract Res Clin Endocrinol Metab. 2011;25(1):25-41.

94 Alatzoglou KS, Webb EA, Le Tissier P, Dattani MT. Isolated growth hormone deficiency (GHD) in childhood and adolescence: recent advances. Endocr Rev. 2014;35(3):376432.

95 Wit JM, Losekoot M, Baumann G. Growth hormone releasing hormone receptor and growth hormone gene abnormalities. In: Cohen L, editor. Growth Hormone Deficiency. 2016.

96 Mullis PE. Genetics of isolated growth hormone deficiency. J Clin Res Pediatr Endocrinol. 2010;2(2):52-62.

97 Wit JM, Kiess W, Mullis P. Genetic evaluation of short stature. Best Pract Res Clin Endocrinol Metab. 2011;25(1):1-17.

98 Kowarski AA, Schneider J, Ben-Galim E, Weldon VV, Daughaday WH. Growth failure with normal serum RIA-GH and low somatomedin activity: somatomedin restoration and growth acceleration after exogenous GH. J Clin Endocrinol Metab. 1978; 47(2):461-4.

99 Frazer T, Gavin JR, Daughaday WH, Hillman RE, Weldon VV. Growth hormone-dependent growth failure. J Pediatr. 1982; 101(1):12-5.

100 Plotnick LP, Van Meter QL, Kowarski AA. Human growth hormone treatment of children with growth failure and normal growth hormone levels by immunoassay: lack of correlation with somatomedin generation. Pediatrics. 1983;71(3):324-7.

101 Bright GM, Rogol AD, Johanson AJ, Blizzard RM. Short stature associated with normal growth hormone and decreased somatomedin- $C$ concentrations: response to exogenous growth hormone. Pediatrics. 1983;71(4):576-80.

102 Takahashi Y, Kaji H, Okimura Y, Goji K, Abe H, Chihara K. Brief report: short stature caused by a mutant growth hormone [see comments]. N Engl J Med. 1996;334(7):4326.

103 Takahashi Y, Kaji H, Okimura Y, Goji K, Abe H, Chihara K. Short stature caused by a mutant growth hormone with an antagonistic effect. Endocr J. 1996;43(Suppl 1):S27-32.

104 Takahashi Y, Shirono H, Arisaka O, Takahashi K, Yagi T, Koga J, et al. Biologically inactive growth hormone caused by an amino acid substitution. J Clin Invest. 1997; 100(5):1159-65

105 Chihara K, Takahashi Y, Kaji H, Goji K, Okimura Y, Abe H. Short stature caused by a natural growth hormone antagonist. Horm Res. 1998;49(Suppl 1):41-5.
106 Millar DS, Lewis MD, Horan M, Newsway V, Easter TE, Gregory JW, et al. Novel mutations of the growth hormone 1 (GH1) gene disclosed by modulation of the clinical selection criteria for individuals with short stature. Hum Mutat. 2003;21(4):424-40.

107 Lewis MD, Horan M, Millar DS, Newsway V, Easter TE, Fryklund L, et al. A novel dysfunctional growth hormone variant (Ile179Met) exhibits a decreased ability to activate the extracellular signal-regulated kinase pathway. J Clin Endocrinol Metab. 2004; 89(3):1068-75.

108 Besson A, Salemi S, Deladoey J, Vuissoz JM, Eble A, Bidlingmaier M, et al. Short stature caused by a biologically inactive mutant growth hormone (GH-C53S). J Clin Endocrinol Metab. 2005;90(5):2493-9.

109 Petkovic V, Besson A, Thevis M, Lochmatter D, Eble A, Fluck CE, et al. Evaluation of the biological activity of a growth hormone (GH) mutant (R77C) and its impact on GH responsiveness and stature. J Clin Endocrinol Metab. 2007;92(8):2893-901.

110 Alatzoglou KS, Turton JP, Kelberman D, Clayton PE, Mehta A, Buchanan C, et al. Expanding the spectrum of mutations in $\mathrm{GH} 1$ and GHRHR: genetic screening in a large cohort of patients with congenital isolated growth hormone deficiency. J Clin Endocrinol Metab. 2009;94(9):3191-9.

111 Petkovic V, Godi M, Pandey AV, Lochmatter D, Buchanan CR, Dattani MT, et al. Growth hormone (GH) deficiency type II: a novel GH-1 gene mutation (GH-R178H) affecting secretion and action. J Clin Endocrinol Metab. 2010;95(2):731-9.

112 Petkovic V, Eble A, Pandey AV, Betta M, Mella P, Fluck CE, et al. A novel GH-1 gene mutation (GH-P59L) causes partial GH deficiency type II combined with bioinactive GH syndrome. Growth Horm IGF Res. 2011;21(3):160-6.

113 Petkovic V, Miletta MC, Boot AM, Losekoot M, Fluck CE, Pandey AV, et al. Short stature in two siblings heterozygous for a novel bioinactive GH mutant (GH-P59S) suggesting that the mutant also affects secretion of the wild-type GH. Eur J Endocrinol. 2013; 168(3):K35-43.

114 Fritez N, Sobrier ML, Iraqi H, Vie-Luton MP, Netchine I, El Annas A, et al. Molecular screening of a large cohort of Moroccan patients with congenital hypopituitarism. Clin Endocrinol (Oxf). 2015;82(6):876-84.

115 Dateki S, Hizukuri K, Tanaka T, Katsumata N, Katavetin P, Ogata T. An immunologically anomalous but considerably bioactive GH produced by a novel GH1 mutation (p.D116E). Eur J Endocrinol. 2009;161(2): 301-6.

116 Sanguineti N, Braslavsky D, Scaglia PA, Keselman A, Ballerini MG, Ropelato MG, et al. p.R209H GH1 variant challenges short stature assessment. Growth Horm IGF Res. 2020;50:23-6.
117 Kojima M, Hosoda H, Date Y, Nakazato M, Matsuo H, Kangawa K. Ghrelin is a growthhormone-releasing acylated peptide from stomach. Nature. 1999;402(6762):656-60.

118 Hassouna R, Labarthe A, Tolle V. Hypothalamic regulation of body growth and appetite by ghrelin-derived peptides during balanced nutrition or undernutrition. Mol Cell Endocrinol. 2016;438:42-51.

119 Sun Y, Wang P, Zheng H, Smith RG. Ghrelin stimulation of growth hormone release and appetite is mediated through the growth hormone secretagogue receptor. Proc Natl Acad Sci USA. 2004;101(13):4679-84.

120 Howard AD, Feighner SD, Cully DF, Arena JP, Liberator PA, Rosenblum CI, et al. A receptor in pituitary and hypothalamus that functions in growth hormone release. Science. 1996;273(5277):974-7.

121 Gnanapavan S, Kola B, Bustin SA, Morris DG, McGee P, Fairclough P, et al. The tissue distribution of the mRNA of ghrelin and subtypes of its receptor, GHS-R, in humans. J Clin Endocrinol Metab. 2002;87(6):2988.

122 Inoue H, Kangawa N, Kinouchi A, Sakamoto Y, Kimura C, Horikawa R, et al. Identification and functional analysis of novel human growth hormone secretagogue receptor (GHSR) gene mutations in Japanese subjects with short stature. J Clin Endocrinol Metab. 2011;96(2):E373-8

123 Wit JM, Oostdijk W, Losekoot M. Spectrum of insulin-like growth factor deficiency. Endocr Dev. 2012;23:30-41.

124 Wit JM, Oostdijk W, Losekoot M, van Duyvenvoorde HA, Ruivenkamp CA, Kant SG. Mechanisms in endocrinology: Novel genetic causes of short stature. Eur J Endocrinol. 2016;174(4):R145-73.

125 Wang HJ, Geller F, Dempfle A, Schauble N, Friedel S, Lichtner P, et al. Ghrelin receptor gene: identification of several sequence variants in extremely obese children and adolescents, healthy normal-weight and underweight students, and children with short normal stature. J Clin Endocrinol Metab. 2004;89(1):157-62.

126 Feighner SD, Howard AD, Prendergast K, Palyha OC, Hreniuk DL, Nargund R, et al. Structural requirements for the activation of the human growth hormone secretagogue receptor by peptide and nonpeptide secretagogues. Mol Endocrinol. 1998;12(1):13745.

127 Pantel J, Legendre M, Cabrol S, Hilal L, Hajaji Y, Morisset S, et al. Loss of constitutive activity of the growth hormone secretagogue receptor in familial short stature. J Clin Invest. 2006;116(3):760-8.

128 Wang W, Tao YX. Ghrelin receptor mutations and human obesity. Prog Mol Biol Transl Sci. 2016;140:131-50.

129 Torz LJ, Osborne-Lawrence S, Rodriguez J, He Z, Cornejo MP, Mustafa ER, et al. Metabolic insights from a GHSR-A203E mutant mouse model. Mol Metab. 2020;39:101004. 
130 Pantel J, Legendre M, Nivot S, Morisset S, Vie-Luton MP, Le Bouc Y, et al. Recessive isolated growth hormone deficiency and mutations in the ghrelin receptor. J Clin Endocrinol Metab. 2009;94(11):4334-41.

131 Pugliese-Pires PN, Fortin JP, Arthur T, Latronico AC, Mendonca BB, Villares SM, et al. Novel inactivating mutations in the $\mathrm{GH}$ secretagogue receptor gene in patients with constitutional delay of growth and puberty. Eur J Endocrinol. 2011;165(2):233-41.

132 Barroso PS, Jorge AAL, Lerario AM, Montenegro LR, Vasques GA, Lima Amato LG, et al. Clinical and genetic characterization of a constitutional delay of growth and puberty cohort. Neuroendocrinology. 2020;110(1112):959-66.

133 Plachy L, Strakova V, Elblova L, Obermannova B, Kolouskova S, Snajderova M, et al. High prevalence of growth plate gene variants in children with familial short stature treated with GH. J Clin Endocrinol Metab. 2019;104(10):4273-81.

134 Hess O, Admoni O, Khayat M, Elias G, Almagor T, Shalev SA, et al. Ghrelin and growth hormone secretagogue receptor (GHSR) genes are not commonly involved in growth or weight abnormalities in an Israeli pediatric population. J Pediatr Endocrinol Metab. 2012;25(5-6):537-40.

135 Liu G, Fortin JP, Beinborn M, Kopin AS. Four missense mutations in the ghrelin receptor result in distinct pharmacological abnormalities. J Pharmacol Exp Ther. 2007; 322(3):1036-43.

136 Dossus L, McKay JD, Canzian F, Wilkening S, Rinaldi S, Biessy C, et al. Polymorphisms of genes coding for ghrelin and its receptor in relation to anthropometry, circulating levels of IGF-I and IGFBP-3, and breast cancer risk: a case-control study nested within the European Prospective Investigation into Cancer and Nutrition (EPIC). Carcinogenesis. 2008;29(7):1360-6.

137 Riedl S, Hughes I, Harris M, Leong GM, Beilby J, Sly P, et al. GH secretagogue receptor gene polymorphisms are associated with stature throughout childhood. Eur J Endocrinol. 2012;166(6):1079-85.

138 Chan Y, Salem RM, Hsu YH, McMahon G, Pers TH, Vedantam S, et al. Genome-wide analysis of body proportion classifies heightassociated variants by mechanism of action and implicates genes important for skeletal development. Am J Hum Genet. 2015;96(5): 695-708.

139 Garcia EA, Heude B, Petry CJ, Gueorguiev M, Hassan-Smith ZK, Spanou A, et al. Ghrelin receptor gene polymorphisms and body size in children and adults. J Clin Endocrinol Metab. 2008;93(10):4158-61.

140 Jung AM, Zenker M, Lissewski C, Schanze D, Wagenpfeil S, Rohrer TR. Genetic polymorphisms as predictive markers of response to growth hormone therapy in children with growth hormone deficiency. Klin Padiatr. 2017;229(5):267-73.
141 Jin Q, Fang XT, Yang L, Zhang CL, Sun JJ, Chen DX, et al. Novel SNPs of the caprine growth hormone secretagogue receptor (GHSR) gene and their association with growth traits in goats. Biochem Genet. 2010; 48(9-10):847-56.

142 Zhang B, Shang P, Tao Z, Qiangba Y, Wang $Z$, Zhang $H$. Effect of a single nucleotide polymorphism in the growth hormone secretagogue receptor (GHSR) gene on growth rate in pigs. Gene. 2017;634:68-73.

143 Ogawa S, Matsuzaki T, Noda M. Abundant expression of the membrane-anchored protease-regulator RECK in the anterior pituitary gland and its implication in the growth hormone/insulin-like growth factor 1 axis in mice. Mol Cell Endocrinol. 2020;508: 110790.

144 Baumann GP. Growth hormone isoforms. Growth Horm IGF Res. 2009;19(4):333-40.

145 Li CH, Dixon JS. Human pituitary growth hormone. 32. The primary structure of the hormone: revision. Arch Biochem Biophys. 1971;146(1):233-6.

146 DeNoto FM, Moore DD, Goodman HM. Human growth hormone DNA sequence and mRNA structure: possible alternative splicing. Nucleic Acids Res. 1981;9(15): 3719-30.

147 Lecomte CM, Renard A, Martial JA. A new natural hGH variant- $17.5 \mathrm{kd}$-produced by alternative splicing. An additional consensus sequence which might play a role in branchpoint selection. Nucleic Acids Res. 1987;15(16):6331-48.

148 Lewis UJ, Singh RN, Tutwiler GF. Hyperglycemic activity of the 20,000-dalton variant of human growth hormone. Endocr Res Commun. 1981;8(3):155-64.

149 Bidlingmaier M, Strasburger CJ. Growth hormone assays: current methodologies and their limitations. Pituitary. 2007;10(2):1159.

150 Hendricks CM, Eastman RC, Takeda S, Asakawa K, Gorden P. Plasma clearance of intravenously administered pituitary human growth hormone: gel filtration studies of heterogeneous components. J Clin Endocrinol Metab. 1985;60(5):864-7.

151 Valenta LJ, Sigel MB, Lesniak MA, Elias AN, Lewis UJ, Friesen HG, et al. Pituitary dwarfism in a patient with circulating abnormal growth hormone polymers. N Engl J Med. 1985;312(4):214-7.

152 Wright DR, Goodman AD, Trimble KD. Studies on "big" growth hormone from human plasma and pituitary. J Clin Invest. 1974;54(5):1064-73.

153 Goffin V, Shiverick KT, Kelly PA, Martial JA. Sequence-function relationships within the expanding family of prolactin, growth hormone, placental lactogen, and related proteins in mammals. Endocr Rev. 1996; 17(4):385-410.

154 Boguszewski CL, Jansson C, Boguszewski MC, Rosberg S, Carlsson B, AlbertssonWikland $\mathrm{K}$, et al. Increased proportion of circulating non-22-kilodalton growth hormone isoforms in short children: a possible mechanism for growth failure. J Clin Endocrinol Metab. 1997;82(9):2944-9.

155 Wagner JK, Eble A, Hindmarsh PC, Mullis PE. Prevalence of human GH-1 gene alterations in patients with isolated growth hormone deficiency. Pediatr Res. 1998;43(1): 105-10.

156 Horan M, Millar DS, Hedderich J, Lewis G, Newsway V, Mo N, et al. Human growth hormone 1 (GH1) gene expression: complex haplotype-dependent influence of polymorphic variation in the proximal promoter and locus control region. Hum Mutat. 2003; 21(4):408-23.

157 den Dunnen JT, Antonarakis SE. Nomenclature for the description of human sequence variations. Hum Genet. 2001;109(1):121-4.

158 de Graaff LC, Clark AJ, Tauber M, Ranke MB, Johnston LB, Caliebe J, et al. Association analysis of ten candidate genes in a large multinational cohort of small for gestational age children and children with idiopathic short stature (NESTEGG study). Horm Res Paediatr. 2013;80(6):466-76.

159 Binder G, Benz MR, Elmlinger M, Pflaum $\mathrm{CD}$, Strasburger CJ, Ranke MB. Reduced human growth hormone (hGH) bioactivity without a defect of the GH-1 gene in three patients with rhGH responsive growth failure. Clin Endocrinol (Oxf). 1999;51(1):8995.

160 Walenkamp MJE, Robers JML, Wit JM, Zandwijken GRJ, van Duyvenvoorde HA, Oostdijk W, et al. Phenotypic features and response to $\mathrm{GH}$ treatment of patients with a molecular defect of the IGF-1 receptor. Clin Endocrinol Metab. 2019;104(8):315771.

161 Guevara-Aguirre J, Torres C, Pena G, Palacios M, Bautista C, Guevara A, et al. IGF-I deficiency and enhanced insulin sensitivity due to a mutated growth hormone receptor gene in humans. Mol Cell Endocrinol. 2021; 519:111044.

162 Hwa V. Human growth disorders associated with impaired GH action: Defects in STAT5B and JAK2. Mol Cell Endocrinol. 2021;519:111063

163 Gutierrez M. Activating mutations of STAT3: impact on human growth. Mol Cell Endocrinol. 2020;518(518):110979.

164 Domene S, Domene HM. The role of acidlabile subunit (ALS) in the modulation of GH-IGF-I action. Mol Cell Endocrinol. 2020;518:111006.

165 Eshet R, Laron Z, Pertzelan A, Arnon R, Dintzman M. Defect of human growth hormone receptors in the liver of two patients with Laron-type dwarfism. Isr J Med Sci. 1984;20(1):8-11.

166 Kofoed EM, Hwa V, Little B, Woods KA, Buckway CK, Tsubaki J, et al. Growth hormone insensitivity associated with a STAT5b mutation. N Engl J Med. 2003;349(12): $1139-47$. 
167 Klammt J, Neumann D, Gevers EF, Andrew SF, Schwartz ID, Rockstroh D, et al. Dominant-negative STAT5B mutations cause growth hormone insensitivity with short stature and mild immune dysregulation. Nat Commun. 2018;9(1):2105.

168 Ramirez L, Sanguineti N, Scaglia P, Keselman A, Ballerini MG, Karabatas L, et al. A novel heterozygous STAT5B variant in a patient with short stature and partial growth hormone insensitivity (GHI). Growth Horm IGF Res. 2020;50:61-70.

169 Scalco RC, Hwa V, Domene HM, Jasper HG, Belgorosky A, Marino R, et al. STAT5B mutations in heterozygous state have negative impact on height: another clue in human stature heritability. Eur J Endocrinol. 2015; 173(3):291-6.

170 Woods KA, Camacho-Hubner C, Savage MO, Clark AJ. Intrauterine growth retardation and postnatal growth failure associated with deletion of the insulin-like growth factor I gene. N Engl J Med. 1996;335(18): 1363-7.

171 Walenkamp MJ, Karperien M, Pereira AM, Hilhorst-Hofstee Y, van Doorn J, Chen JW, et al. Homozygous and heterozygous expression of a novel insulin-like growth factor-I mutation. J Clin Endocrinol Metab. 2005;90(5):2855-64.

172 Keselman AC, Martin A, Scaglia PA, Sanguineti NM, Armando R, Gutierrez M, et al. A homozygous mutation in the highly conserved Tyr60 of the mature IGF1 peptide broadens the spectrum of IGF1 deficiency. Eur J Endocrinol. 2019;181(5):K43-53.

173 Netchine I, Azzi S, Houang M, Seurrin D, Daubas C, Ricor JM, et al. Partial IGF-I deficiency demonstrates the critical role of IGF-I in growth and brain development. Horm Res. 2006;65(Suppl 4):29.

174 van Duyvenvoorde HA, van Setten PA, Walenkamp MJ, van DJ, Koenig J, Gauguin $\mathrm{L}$, et al. Short stature associated with a novel heterozygous mutation in the insulin-like growth factor 1 gene. J Clin Endocrinol Metab. 2010;95(11):E363-7.

175 Fuqua JS, Derr M, Rosenfeld RG, Hwa V. Identification of a novel heterozygous IGF1 splicing mutation in a large kindred with familial short stature. Horm Res Paediatr. 2012;78(1):59-66.

176 Batey L, Moon JE, Yu Y, Wu B, Hirschhorn JN, Shen Y, et al. A novel deletion of IGF1 in a patient with idiopathic short stature provides insight Into IGF1 haploinsufficiency. J Clin Endocrinol Metab. 2014;99(1):E153-9.

177 van Duyvenvoorde HA, van DJ, Koenig J, Gauguin L, Oostdijk W, Wade JD, et al. The severe short stature in two siblings with a heterozygous IGF1 mutation is not caused by a dominant negative effect of the putative truncated protein. Growth Horm IGF Res. 2011;21(1):44-50

178 Woods KA, Fraser NC, Postel Vinay MC, Savage MO, Clark AJ. A homozygous splice site mutation affecting the intracel- lular domain of the growth hormone (GH) receptor resulting in Laron syndrome with elevated GH-binding protein [see comments]. J Clin Endocrinol Metab. 1996; 81(5):1686-90.

179 Domene HM, Bengolea SV, Martinez AS, Ropelato MS, Pennisi P, Scaglia P, et al. Deficiency of the circulating insulin-like growth factor system associated with inactivation of the acid-labile subunit gene. $\mathrm{N}$ Engl J Med. 2004;350(6):570-7.

180 Isik E, Haliloglu B, van Doorn J, Demirbilek $\mathrm{H}$, Scheltinga SA, Losekoot M, et al. Clinical and biochemical characteristics and bone mineral density of homozygous, compound heterozygous and heterozygous carriers of three novel IGFALS mutations. Eur J Endocrinol. 2017;176(6):657-67.

181 Domene HM, Scaglia PA, Martinez AS, Keselman AC, Karabatas LM, Pipman VR, et al. Heterozygous IGFALS gene variants in idiopathic short stature and normal children: impact on height and the IGF system. Horm Res Paediatr. 2013;80(6):413-23.

182 Ester WA, van Duyvenvoorde HA, de Wit CC, Broekman AJ, Ruivenkamp CA, Govaerts LC, et al. Two short children born small for gestational age with insulin-like growth factor 1 receptor haploinsufficiency illustrate the heterogeneity of its phenotype. J Clin Endocrinol Metab. 2009;94(12):471727.

183 Giabicani E, Willems M, Steunou V, Chantot-Bastaraud S, Thibaud N, Abi Habib W, et al. Increasing knowledge in IGF1R defects: lessons from 35 new patients. J Med Genet. 2020;57(3):160-8.

184 Malaquias AC, Jorge AAL. Activation of the MAPK pathway (RASopathies) and partial growth hormone insensitivity. Mol Cell Endocrinol. 2021;519:111040.

185 Hanson D, Murray PG, Coulson T, Sud A, Omokanye A, Stratta E, et al. Mutations in CUL7, OBSL1 and CCDC8 in 3-M syndrome lead to disordered growth factor signalling. J Mol Endocrinol. 2012;49(3):267-75.

186 Ostrovsky O, Ahmed NT, Argon Y. The chaperone activity of GRP94 toward insulinlike growth factor II is necessary for the stress response to serum deprivation. $\mathrm{Mol}$ Biol Cell. 2009;20(6):1855-64.

187 Marzec M, Hawkes CP, Eletto D, Boyle S, Rosenfeld R, Hwa V, et al. A human variant of glucose-regulated protein 94 that inefficiently supports IGF production. Endocrinology. 2016;157(5):1914-28.

188 Backeljauw PF, Kuntze J, Frane J, Calikoglu AS, Chernausek SD. Adult and near-adult height in patients with severe insulin-like growth factor-I deficiency after long-term therapy with recombinant human insulinlike growth factor-I. Horm Res Paediatr. 2013;80(1):47-56

189 Grandone A, Miraglia del Giudice E, Cirillo G, Abbondanza C, Cioffi M, Romano T, et al. Clinical features of a new acid-labile subunit (IGFALS) heterozygous mutation: an- thropometric and biochemical characterization and response to growth hormone administration. Horm Res Paediatr. 2014; 81(1):67-72.

190 Rohrer TR, Abuzzahab J, Backeljauw P, Birkegård AC, Blair J, Dahlgren J, et al. Long-term effectiveness and safety of childhood growth hormone treatment in Noonan syndrome. Horm Res Paediatr. 2020;93(6) 380-95.

191 Leger J, Fjellestad-Paulsen A, Bargiacchi A, Doyen C, Ecosse E, Carel JC, et al. Can growth hormone treatment improve growth in children with severe growth failure due to anorexia nervosa? A preliminary pilot study. Endocr Connect. 2017;6(8):839-46.

192 Ranke MB, Wit JM. Growth hormone: past, present and future. Nat Rev Endocrinol. 2018;14(5):285-300.

193 Filopanti M, Ronchi C, Ballare E, Bondioni S, Lania AG, Losa M, et al. Analysis of somatostatin receptors 2 and 5 polymorphisms in patients with acromegaly. J Clin Endocrinol Metab. 2005;90(8):4824-8.

194 Johansson M, McKay JD, Wiklund F, Rinaldi S, Hallmans G, Balter K, et al. Genetic variation in the SST gene and its receptors in relation to circulating levels of insulin-like growth factor-I, IGFBP3, and prostate cancer risk. Cancer Epidemiol Biomarkers Prev. 2009;18(5):1644-50.

195 Denef C. Paracrinicity: the story of 30 years of cellular pituitary crosstalk. J Neuroendocrinol. 2008;20(1):1-70.

196 Kano M, Suga H, Arima H. Induction of functional hypothalamus and pituitary tissues from pluripotent stem cells for regenerative medicine. J Endocr Soc. 2021;5(3): bvaa 188 .

197 Joustra SD, Heinen CA, Schoenmakers N Bonomi M, Ballieux BE, Turgeon MO, et al. IGSF1 deficiency: lessons from an extensive case series and recommendations for clinical management. J Clin Endocrinol Metab. 2016;101(4):1627-36.

198 Joustra SD, Meijer OC, Heinen CA, Mol IM, Laghmani el H, Sengers RM, et al. Spatial and temporal expression of immunoglobulin superfamily member 1 in the rat. J Endocrinol. 2015;226(3):181-91.

199 Joustra SD, Roelfsema F, van Trotsenburg ASP, Schneider HJ, Kosilek RP, Kroon HM, et al. IGSF1 deficiency results in human and murine somatotrope neurosecretory hyperfunction. J Clin Endocrinol Metab. 2020; 105(3):e70-e84.

200 Wakeling EL, Brioude F, Lokulo-Sodipe O, O'Connell SM, Salem J, Bliek J, et al. Diagnosis and management of Silver-Russell syndrome: first international consensus statement. Nat Rev Endocrinol. 2017;13(2):10524.

201 Pedreira CC, Savarirayan R, Zacharin MR. IMAGe syndrome: a complex disorder affecting growth, adrenal and gonadal function, and skeletal development. J Pediatr. 2004;144(2):274-7. 
202 Bens S, Haake A, Richter J, Leohold J, Kolarova J, Vater I, et al. Frequency and characterization of DNA methylation defects in children born SGA. Eur J Hum Genet. 2013; 21(8):838-43.

203 Stalman SE, Solanky N, Ishida M, AlemanCharlet C, Abu-Amero S, Alders M, et al. Genetic analyses in small-for-gestationalage newborns. J Clin Endocrinol Metab. 2018;103(3):917-25.

204 Diets IJ, van der Donk R, Baltrunaite K, Waanders E, Reijnders MRF, Dingemans AJM, et al. De novo and inherited pathogenic variants in KDM3B cause intellectual disability, short stature, and facial dysmorphism. Am J Hum Genet. 2019;104(4):758-66.

205 Ibarluzea N, Hoz AB, Villate O, Llano I, Ocio I, Marti I, et al. Targeted next-generation sequencing in patients with suggestive $\mathrm{X}$ linked intellectual disability. Genes (Basel). 2020;11(1):51.
206 Chorin O, Yachelevich N, Mohamed K, Moscatelli I, Pappas J, Henriksen K, et al. Transcriptome sequencing identifies a noncoding, deep intronic variant in CLCN7 causing autosomal recessive osteopetrosis. Mol Genet Genomic Med. 2020;8(10): e1405.

207 Rentas S, Rathi KS, Kaur M, Raman P, Krantz ID, Sarmady M, et al. Diagnosing Cornelia de Lange syndrome and related neurodevelopmental disorders using RNA sequencing. Genet Med. 2020;22(5):927-36.

208 Sparber P, Filatova A, Khantemirova M, Skoblov M. The role of long non-coding RNAs in the pathogenesis of hereditary diseases. BMC Med Genomics. 2019;12(Suppl 2):42.

209 Cirillo F, Catellani C, Lazzeroni P, Sartori C, Street ME. The role of MicroRNAs in influencing body growth and development. Horm Res Paediatr. 2020;93(1):7-15.
210 Cheng Y, Chen T, Song J, Qi Q, Wang C, Xi Q, et al. miR-709 inhibits GHRP6 induced GH synthesis by targeting PRKCA in pituitary. Mol Cell Endocrinol. 2020;506: 110763.

211 Mas-Pares B, Xargay-Torrent S, Bonmati A, Lizarraga-Mollinedo E, Martinez-Calcerrada JM, Carreras-Badosa G, et al. Umbilical cord miRNAs in small-for-gestational-age children and association with catch-up growth: a Pilot study. J Clin Endocrinol Metab. 2019;104(11):5285-98.

212 Wright CF, McRae JF, Clayton S, Gallone G, Aitken S, FitzGerald TW, et al. Making new genetic diagnoses with old data: iterative reanalysis and reporting from genome-wide data in 1,133 families with developmental disorders. Genet Med. 2018;20(10):121623. 